\title{
A koordinációs folyamatok intézményi hátterének evolúciója a magyar nemzetbiztonsági igazgatásban
}

\author{
Evolution of the Institutional Background of Coordination \\ Mechanism in the National Security Administration
}

Magyarországon az állambiztonsági szervezet felbomlását követően - történeti és politikai okok folytán - osztott nemzetbiztonsági intézményrendszer alakult ki. Ezt a jellemvonását a hazai titkosszolgálati struktúra a napjainkig végrehajtott átalakitásokat követöen is megörizte. A fentiekre tekintettel az elmúlt közel három évtizedben - hol az állami intézmények összehangolt reagálást igénylő biztonsági kihívások, hol költségvetési szükségszerüségek folytán - a szakmai-politikai diskurzus visszatérö elemként merült fel a nemzetbiztonsági szektorban müködő koordinációs folyamatok hatékonyságának kérdése. A tanulmány - a történelmi elözmények és az 1990 és 2018 között intézményi megoldások vázlatos áttekintésével párhuzamosan - elsősorban a polgári nemzetbiztonsági szolgálatok számára történő feladatszabás, valamint a döntés-elökészítési folyamatokat támogató kormányzati tájékoztató rendszer összehangolásával kapcsolatos elgondolásokra kivánt fókuszálni. A korszakolt áttekintés vizsgálni kívánta azokat a gyakran egymással ütközö szakpolitikai koncepciókat, megközelítéséket is, amelyek orientálták a hazai nemzetbiztonsági szférában jelenleg müködő koordinációs mechanizmusok kialakulását.

Kulcsszavak: nemzetbiztonsági igazgatás, koordinációs intézmények, együttmüködési modellek

In Hungary, due to historical and political reasons a split system of national security institutions was established following the disintegration of the state security organisation. Until now, this characteristic feature regarding the structure of the domestic secret services remained the same throughout the implemented structural transformations. Having said that, the question of effectiveness of the coordination processes within 
the national security sector has been a reoccurring topic of political and professional discussions in the last three decades. The study, while provides a brief review on the institutional resolutions between the period of 1990 and 2018, primarily aims to focus on the concept of tasks delegated to the civilian national security services and on the ideas related to the coordination of the governmental information system supporting decision-making processes. The periodical review also intends to examine the often conflicting professional concepts and approaches, which provided orientation to the development of the currently existing coordination mechanisms used in the domestic national security sector.

Keywords: national security administration, institutions for coordination, models of cooperation

\section{Az osztott nemzetbiztonsági struktúrák jellemvonásai és a koordináció intézményi formái}

Az elmúlt évtizedben több tanulmány, illetve a témakört részben érintő monografikus munka jelent meg a hazai nemzetbiztonsági struktúra felépítéséről és múködéséről, érintve az egyes intézmények kialakulásának hátterében azonosítható biztonsági kihívásokat, valamint történeti és közpolitikai folyamatokat. ${ }^{2}$ Jelen tanulmány ezért a koordinációs intézmények kialakulásának és jellemvonásainak áttekintése során eltekintett a magyar nemzetbiztonsági struktúra elemeinek átfogó vizsgálatától. A szervezeti megoldások, illetve az ezeket formáló szakpolitikai koncepciók korszakolt áttekintése előtt - az elemzésben használt fogalmak lehatárolása érdekében - célszerü röviden áttekinteni azokat a titkosszolgálati rendszermodelleket, amelyeknek számos eleme visszaköszönt az elmúlt három évtized hazai intézményi fejlődésében.

A 20. század második felében a több titkosszolgálattal rendelkező államokban a nemzetbiztonsági struktúrák müködésének alapvetően három típusa alakult ki. ${ }^{3}$ Fontos hangsúlyozni, hogy az egyes modellekhez kapcsolódó elemek számos ország esetében párhuzamosan jelen vannak. Érvényesülésük többnyire az adott állam történelmi hagyományait, alkotmányos berendezkedésének sajátosságait, az országot

\footnotetext{
A szerző az elemzés lehatárolásánál a forrásjegyzékben szereplő munkák közül kiemelten támaszkodott Boda József nemzetbiztonsági tevékenységet komplexen bemutató monográfiájának történeti és institucionalista megközelítéssel írt fejezeteire (2016), Kovács Zoltán Andrásnak és Dobák Imrének az intézményrendszer kialakulását, jellemzőit, illetve az ezt befolyásoló tényezőket átfogóan elemző tanulmányára (2017), valamint Dávid Ferencnek a magyar nemzetbiztonsági szféra első bő két évtizedének múködési kereteit rendvédelmi kitekintéssel tárgyaló írására (2017). A témakört az utóbbi tanulmánynál valamivel szúkebb időkeretben, a politikai rendszer oldaláról vizsgálja Kurtán Sándor (2009). A hazai intézményrendszer 20. századi történeti gyökereinek - vázlatos keretek közötti - áttekintését segítette a Dialóg Campus gondozásában a hírszerzés történetét az ókortól napjainkig áttekintő tanulmánykötet magyar vonatkozású, összegző fejezeteinek megjelenése is (2019).

3 A tanulmányban is érintett modellek országokra vetített példákkal illusztrált áttekintését nyújtja: HÉJJA 2014, 57-64.
} 
érintő biztonsági kihívásokat, valamint a releváns politikai érdekcsoportok (elsősorban a kormányzó pártok) aktuális erőviszonyait és ambícióit is visszatükrözik. ${ }^{4}$

Elsőként az Egyesült Államokban az ezredforduló előtti évtizedekben múködtetett „versengő modell” említhető. Ebben a rendszerben a szolgálatok a saját múveleti képességek felhasználásával megszerzett információkat, illetve az ezekre épülő elemzéseket közvetlenül juttatják el a döntéshozók asztalára. Ennek a modellnek a legfőbb erőssége, hogy biztosítja valamennyi szolgálat álláspontjának kormányzati szinten történő megjelenítését, ütköztetését. A szolgálatok vezetői, vagy kapcsolattartó szakértői gyakran a szóban megtett tájékoztatás (briefing) közben, személyesen gyűjtik be az új hírigényeket és a korábbi elemzéseikkel kapcsolatos visszajelzéseket a jelentések címzettjétől vagy annak tanácsadójától. ${ }^{5}$ A konkrét információs igények teljesítése mellett a kormányzati központokba „,bekötött” hírszerző szervek tájékoztató anyagaik tematikáját, illetve jelentések megküldésének ütemezését sokszor az érintett állami vezető naptárjában szereplő eseményekhez, tárgyalásokhoz igazítják. A versengő modell müködtetésének ára, hogy az érintett államnak minden szolgálat esetében finanszíroznia kell az önálló információszerző kapacitások és elemző-értékelő stábok múködését. Emellett a döntés-előkészítés folyamatában, vagy stratégiai irányvonalak meghatározásánál a szolgálatoktól párhuzamosan, néha egymást átfedő témakörben beérkező jelentések szintetizálása, az ellentmondások feloldása a döntéshozóra hárul, szerencsésebb esetben a tevékenységét segítő szakértői stáb bevonásával.

A hírszerzés és elhárítás 20. századi egyetemes és hazai történetét vizsgálva domináns elemként találkozhatunk a „szektoriális modellel”, amelyben a különböző szolgálatok egycsatornás rendszerben küldik meg az információikat a kormányzati irányításukat végző döntéshozónak. A nemzetbiztonsági intézmények ebben az esetben jellemzően a legnagyobb hírfogyasztójukat szolgálják ki, így a hírszerzés a külügyi tárca irányítóját vagy közvetlenül az ország első számú vezetőjének (államfő/kormányfő) hivatalát, a katonai szolgálatok a hadügyminisztert, míg a biztonsági/elhárító szolgálatok többnyire a belügyminisztert tájékoztatják. Ennek a megoldásnak az előnye, hogy az egyes tárcák vezetői könnyebben juthatnak az őket igazán érdeklő információkhoz. Megfelelő koordinációs mechanizmusok alkalmazása nélkül azonban e rendszer hátránya lehet, hogy a más minisztériumok, illetve állami szervek számára is releváns információk sokszor nem kerülnek időben az illetékes kormányzati szereplők kezébe, veszélyeztetve az eredményes döntéshozatalt. Ennek kockázata jelentős mértékben megnövekedhet olyan koalíciós kormányzatok estén, ahol a szolgálatokat irányító tárcákat birtokló pártok közötti bizalmatlanság vagy belpolitikai ellentét alakul ki.

Végül elérkeztünk a tanulmány fókuszpontjában álló „együttmüködő modellhez”, ahol a szolgálatok önállóságukat megőrizve, esetenként osztott kormányzati irányítás mellett, de a köztük lévő koordináció intézményesített formáit (országonként eltérő mélységben) kialakító rendszerben múködnek. A nemzetbiztonsági szférában az együttmúködését segítő mechanizmusok körében érdemes elkülönítve vizsgálni a szolgálatok egységes kormányzati irányítását és feladatszabását biztosító intézményeket, illetve

A külföldi nemzetbiztonsági struktúrák, illetve az ezekbe illesztett koordinációs intézmények közelmúltban megjelent, átfogó összehasonlító leírását tartalmazza: BÉREs 2018.

A hírszerző és a döntéshozó közötti közvetlen kapcsolat sajátosságait vizsgálja: RoLınGTON 2015, $144-148$. 
URBÁN ATTILA: A koordinációs folyamatok intézményi hátterének evolúciója...

a nemzetbiztonsági szervek horizontális együttműködését támogató eljárásokat. A kooperáló modellnek a létrehozásában meghatározó szerepet játszott az Egyesült Királyság, ${ }^{6}$ de különböző változataival - a bipoláris világrend felbomlása után előtérbe kerülő új típusú biztonsági kihívásokhoz való alkalmazkodás jegyében - az elmúlt két évtizedben az euroatlanti térség államainak egyre bővülő körénél találkozhatunk. Az együttmúködés intézményi hátterét kialakító rendszerek fontos jellemvonása, hogy biztonságpolitika terén feladattal rendelkező tárcák vezetőinek részvételével összeülő testületek - jellemzően kabinetek vagy tanácsok ${ }^{7}$ - mellett a szolgálatok számára megfogalmazott hírigények kiosztását, valamint a tőlük beérkező információk koordinált felhasználását végző szervezet is múködik. Fontos kiemelni, hogy az együttműködő rendszereket működtető államok jelentős részénél a szolgálatok (jellemzően a hírszerzés) megőrzik a döntéshozók közvetlen tájékoztatásának lehetőségét is. Egyes kooperatív rendszerekben többek között találkozhatunk:

- a szolgálatok és a rendvédelmi szervek vezetőiből álló koordinációs testülettel, ahol a napirendre kerülő kérdésekben ügyhöz kötött múveleti és elemzői együttmúködés valósítható meg;

- a kormányzati struktúrába illesztett, önálló (többségében a szolgálatoktól vezényelt) szakértői stábbal múködő, a döntéshozatali centrumba „,bekötött” vezető által irányított szervezetekkel; ${ }^{9}$

- valamint kiterjedt elemzői állománnyal, esetenként nemzetbiztonsági szolgálatokhoz hasonló jogállással rendelkező, de önálló hírszerző tevékenységet nem folytató információfúziós intézményekkel. ${ }^{10}$

A kooperatív modell kétségtelen előnye, hogy az adott ügyekhez kapcsolódóan a felesleges párhuzamosságok csökkenthetők, a nemzeti szinten rendelkezésre álló humán és technikai képességek pedig koordináltan használhatók fel a múveleti és az elemző-értékelő munkában. Emellett a fenti rendszerben keletkező tájékoztató anyagok törvényszerűen átfogóbb képet nyújtanak az érintett döntéshozók számára. Ugyanakkor az együttmüködő rendszerek múködésének is megvan a kockázata: az egyes kérdésekhez kapcsolódó véleménykülönbségeket - jellemzően a kormányzati célkitűzésekhez igazítva - esetenként már a koordinációs testületben, szakértői szinten elsimítják, így a döntéshozók asztalán sokszor már csak a legkisebb közös

6 A brit „kooperáló” modell kialakulását és működését az Egyesített Hírszerző Bizottságban (JIC), illetve a Kormányzati Kommunikációs Központ (GCHQ) élén szerzett tapasztalatai tükrében elemzi: OMAND 2011.

7 A rendszerváltást követően hazánkban létrejött Nemzetbiztonsági Kabinet mellett például ebbe körbe sorolható Ausztriában a kancellár, Nagy-Britanniában a miniszterelnök, az Egyesült Államokban pedig az elnök irányítása alatt álló Nemzetbiztonsági Tanács.

8 Erre a szervezeti formára jelent példát itthon a Nemzetbiztonsági Kabinet támogatására 2010 után létrejött, a szolgálatok és a rendvédelmi szervek vezetőit tömörítő Nemzetbiztonsági Munkacsoport.

9 A fenti megoldást alkalmazó brit JIC vezetője a szolgálatoktól és a biztonságpolitika formálása szempontjából meghatározó minisztériumoktól beérkező információkat összegezve tájékoztatja a kormányfőt, illetve a kormányzati hírigényeket határoz meg a hírszerző és elhárító szervek számára.

10 Az Amerikai Egyesült Államok markáns kompetitív jegyeket magán viselő Hírszerző Közösségének (IC) az országot 2001 szeptemberében ért terrortámadásokat követő években végrehajtott átalakítása eredményeként jött létre a szolgálatok tevékenységét koordináló Nemzeti Hírszerző Főigazgató (DNI) tisztsége. A közvetlenül az elnöknek jelentő DNI munkáját a 2010-es évek elején már egy 1750 főből (jelentős részben elemző-értékelő munkatársakból) álló szervezet támogatta. A jelenleg 17 szervezetből álló IC működéséről átfogó képet nyújt: LOWENTHAL 2017. 
nevezőre alapozott vélemények jelennek meg. Szerencsésebb esetben a kormányzat számára felterjesztett jelentések tartalmazzák az eltérő értékeléseket (és az ezekből fakadó döntési opciókat), ám a koordinációs testület vezetője a lehetséges alternatívákat ilyenkor is megpróbálhatja redukálni. Természetesen a döntéshozó előzetes elvárásai által determinált tájékoztatás dilemmája ${ }^{11}$ nem a kooperatív modell sajátossága, az esetenként a versengő és a szektoriális rendszerekben is érvényesülhet.

\section{A magyar titkosszolgálatok közötti intézményesített együttmúködés történelmi hagyományai a „rövid” 20. században}

Az önálló magyar államiság 20. századi helyreállítása után, az első világháború lezárását követően Magyarországon - a korábbi történeti mintákat, elsősorban az Osztrák-Magyar Monarchia hírszerzési hagyományait követve - intézményileg osztott titkosszolgálati struktúra és ehhez igazodó hivatásrendi szervezet alakult ki. A két világháború közötti időszakban - a korszak biztonsági kihívásainak megfelelve - a kormányzat diplomáciai és belpolitikai információs igényeit is kielégítő, a hírszerzést és az elhárítást egységes intézményi rendben működtető katonai titkosszolgálat (VKF 2. osztály) játszott domináns szerepet a Belügyminisztérium irányítása alá tartozó politikai rendészet, illetve a közös HM-BM közös alárendeltségben múködő csendőrség nyomozó szerveihez képest. A fenti szervezetek titkos információgyújtő tevékenysége leginkább a rendszerkritikus politikai csoportok elleni hazai felderítőtevékenység területén került átfedésbe.

Magyarország történetében első ízben a második világháború kényszerítette ki a titkosszolgálati tevékenység intézményesített koordinációját. Az érintett szervezetek illetékes vezetőivel a 1942 nyarán a belügyminiszter irányítása alatt, a 6290. BM és a HM 1942. Eln. 1/52.161. számú rendeletekkel felállított Államvédelmi Központ (a továbbiakban: ÁVK) vezetője rendszeresen egyeztetett a hírszerző és államrendészeti szervek parancsnokaival. A szervezet kezdetben heti rendszerességgel megtartott vezetői értekezletek napirendjén áttekintették a kiemelt belföldi felderítési irányokban folyó ügyeket. Az ÁVK közvetlen műveleti munkában csak összekötőként közreműködő, vezényelt munkatársai értékelték a felderítőszervektől beérkező információkat, illetve az ezekre alapozott tájékoztató jelentéseket készítettek. A szervezet vezetője az összesített adatok alapján javaslatot tehetett nyomozás elrendelésére. ${ }^{12}$ A tevékenységét értékelő források tükrében megállapítható, hogy az ÁVK bázisán

11 Lowenthal (329-332.) mellett a hírszerző értékelések objektivitásával kapcsolatos elvárásokra, a jelentéseket összeállító elemző és az azokat felhasználó döntéshozó esetenként eltérő szemléletéből fakadó dilemmákra világít rá: JENSEN et al. 2017, 30-31. A fenti témakört - elsősorban az angolszász szakirodalom tükrében - szintén vizsgálja: KURTÁN 2008, 134-136.

12 Az ÁVK vezetőjének, Ujszászy István vezérőrnagynak a szervezet felépítésével és működésével kapcsolatos feljegyzéseit közli, illetve a források kritikai elemzését nyújtja: HARASZTI 2007. 
URBÁN ATTILA: A koordinációs folyamatok intézményi hátterének evolúciója...

megvalósult együttműködés csak korlátozottan volt képes enyhíteni a korabeli titkosszolgálati struktúra versengő és szektoriális jellemvonásait. ${ }^{13}$

A második világháborút követően megszervezett titkosszolgálati rendszer szerkezete - a HM Katonapolitikai Osztály és a BM Politikai Rendészeti Osztály felállításával - a két világháború közötti alapokra épült. A frontvonal áthaladását követően megszervezett új felderítőszervek azonnal a Magyar Kommunista Párt (MKP) ellenőrzése alá kerültek. Ennek megfelelően múködésének fő irányait az MKP, majd a szovjet minta szerint átalakított politikai rendszerben a közvetlen pártirányítási csatornákon keresztül a mindenkori állampárt (MDP/MSZMP) vezetése határozta meg. A pártszervezeten belül megvalósuló koordinált irányítás központi intézménye az MDP Katonai és Belügyi Bizottságának összevonásával, 1948 szeptemberében létrehozott Államvédelmi Bizottság lett. Ennek ülésein a párt legszúkebb vezetésén túl a külügyi, a belügyi és a honvédelmi tárca irányítói, valamint az BM ÁVH és a „Katpol” vezetői is jelen voltak. Ez utóbbi szervezetnek a Rajk-per időszakában történő „lefejezése”, valamint a katonai elhárítási területnek a belügyi tárcától is lényegében függetlenedő ÁVH-ba integrálása megbontotta az addig egységes katonai titkosszolgálatot. 1949 végétől így - a HM és a Magyar Néphadsereg hírigényéhez igazodó katonai felderítés kivételével - a múveleti munka politikai főirányait meghatározó legszúkebb pártvezetésének, jellemzően közvetlenül Rákosinak referáló Péter Gábor kezében összpontosult a korabeli államvédelmi tevékenység integrált szakmai irányítása. ${ }^{14}$

A magyar titkosszolgálati struktúra rendszerváltásig érvényes alapszerkezetét az első Nagy Imre-kormány megalakulását követően, 1953-ban nyerte el. Ekkor került sor honvédelmi tárca felügyelete alatt álló a katonai hírszerzés, azaz a Magyar Néphadsereg Vezérkarának 2. Csoportfőnöksége (MNVK-2) és a Belügyminisztérium intézményrendszerébe visszaintegrált, de a rendőrségtől továbbra is elkülönülő államvédelmi szervezet kialakítására. 1953 után az államvédelem területét érintő párthatározatok egyik legfontosabb eleme a pártellenőrzés szélesítésének kérdése lett. Mindez azonban nem változtatott azon a gyakorlaton, hogy a legérzékenyebb, jellemzően kémelhárítási és nemzetközi vonatkozású továbbra is csak a legszúkebb pártvezetés kapta meg. Az 1956-os forradalom leverését követően az államvédelmi szolgálatok bázisán alakult meg a BM Politikai Nyomozó Főosztály, amely továbbra is magában foglalta a katonai elhárítás területét. A Kádár-rendszer fokozatos konszolidációjával párhuzamosan, 1962-ben sor került a Belügyminisztérium átfogó intézményi reformjára. Az ekkor létrejött BM III. (Állambiztonsági) Főcsoportfőnökség csoportfőnökségi szerkezete a rendszerváltásig stabilnak bizonyult. ${ }^{15}$

\footnotetext{
13 Az ÁVK múveleti tevékenység koordinációját célzó feladatainak hatékony végrehajtását, illetve az információk mélységi megosztását mindvégig korlátozták a (háború kedvezőtlen alakulása folytán mind inkább egyensúlyi politikára törekvő) konzervatív belügyi vezetés, valamint a (Németországgal egyre szorosabb együttműködést kezdeményező) Honvéd Vezérkar közötti politikai törésvonalak és hatásköri viták. A témakör bővebb áttekintését nyújtja: VARGA 2015, 194-208.

14 A pártvezetés szervei által koordinált irányítási tevékenységét, a hírigények megfogalmazását és az államvédelem integrált tájékoztató rendszerének sajátosságait mutatja be: MüLLER 2012, 127-144.

15 A BM III. Főcsoportfőnökség megszervezését, valamint az 1970-es évek első felében - a Magyar Népköztársaság dinamikusan bővülő nemzetközi kapcsolataihoz, illetve a változó pártállami hírigényekhez és elvárásokhoz igazodó - állambiztonsági tevékenység szervezeti kereteit és módszertani korszerűsítését tekinti át: URBÁN 2003, 3-75.
} 


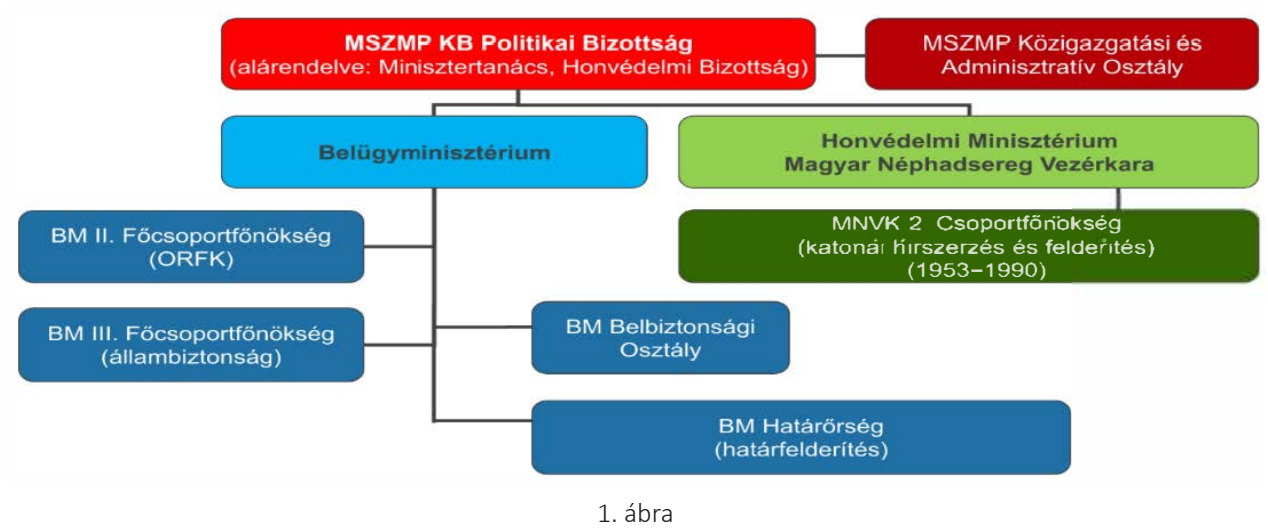

A titkos információgyüjtést folytató szervek pártállami irányitása (1962-1989)

Forrás: a szerző szerkesztése

A fenti ábrán látható, hogy a belügyi és a honvédelmi tárca alárendeltségében múködtetett titkosszolgálati rendszer koordinációja a Kádár-korszakban sem a Minisztertanács, hanem központi pártszervek szintjén valósult meg. Az MSZMP KB Politikai Bizottságának 1957. november 12-i, valamint 1967. november 14-i határozatai jelölték ki a pártirányítás szerepét és rendjét a belügyi, ezen belül az állambiztonsági munka területén. A Központi Bizottság hatáskörébe került „az ellenség elleni harc irányainak és közvetlen feladatainak" meghatározása. A KB Titkársága felügyelte a szolgálatoknál múködő pártalapszervezetek múködését. A KB Közigazgatási és Adminisztrativ Osztálya ellenőrizte a pártvezetés által kiadott feladatok végrehajtását. A szolgálatokat érintő fontosabb személyügyi kérdések mellett a Politikai Bizottság kapott felhatalmazást arra, hogy „meghallgassa a minisztert a politikai jellegű ügyek vizsgálatáról, és döntsön a munka folytatásáról”."16

Az 1960-as évek második felében a rendszerváltásig állandósult szervezeti formát kapott az állambiztonsági tevékenység egyes ágazatainak koordinált szakmai vezetése. A BM III. Főcsoportfőnökség 1967-es ügyrendjében jelent meg első ízben a főcsoportfőnök véleményező és tanácsadó testülete, a Csoportfőnöki Értekezlet. A testület állandó tagjai voltak a csoportfőnökök, a III/1. (vizsgálati) és a III/4. (elemző-értékelő) osztály vezetői, valamint azok a vezetők, akik az egyes napirendi pontok tárgyalásához a főcsoportfőnök berendelt vagy meghívott. „Állandó meghívottként” részt vett az üléseken az MSZMP KB Közigazgatási és Adminisztratív Osztály képviselője, a BM Politikai Bizottságának első titkára. ${ }^{17}$ Mai szóhasználattal élve a testület ülésén egy asztalnál ültek a hírigényt megfogalmazó döntéshozók képviselői, valamint - az MNVK-2 kivételével - valamennyi klasszikus titkosszolgálati ágazat vezetői. Az ülést vezető főcsoportfőnök (miniszter-helyettes) számolt be a BM Kollégiumának

\footnotetext{
16 Az állambiztonsági szervek pártirányításának Kádár-korszakban kezdetén kialakított rendszerét mutatja be: KRAHULCSÁN 2013.

$17 \quad$ www.abparancsok.hu/sites/default/files/parancsok/10_1837_1967.pdf (A letöltés dátuma: 2019. 11. 01.)
} 
(mai kifejezéssel parancsnoki értekezletének) ülésén az állambiztonsági vonatkozású kérdésekben, egyúttal felelt a pártvezetés és a kormány tagjainak tájékoztatásáért. A fenti irányítási modell lehetővé tette a napirenden szereplő állambiztonsági kérdések viszonylag komplex áttekintését és a feladatok koordinált kiadását. A Csoportfőnöki Értekezlet állandó tagjai közül „hiányzó” katonai hírszerzéssel folytatott együttmúködés rendjét a HM és a BM által kiadott közös parancsok, illetve az erre épülő együttes utasítások szabályozták.

Az 1970-es évek elején az állambiztonsági elemző-értékelő szakterület bevonásával a BM Információ-feldolgozó és Felügyeleti Csoportfőnökség megalakítása, majd ennek bázisán 1977-ben a BM Adatfeldolgozó Csoportfönökség létrehozása az integrált állambiztonsági és rendvédelmi tájékoztató rendszer megvalósítást jelentette. A korszak döntéshozói felé kialakított, valamennyi állambiztonsági szakterület információit összesítő mechanizmus érvényesült az évtized végén létrehozott „napi operatív információs jelentések” rendszerében. Az 1980-as évek elejétől a tájékoztatókat - a belügyminiszteri jóváhagyás után - megküldték az MSZMP PB tagjainak, a KB titkárainak, az Elnöki Tanács és az Országgyúlés Elnökének, valamint a Minisztertanács elnökének és helyetteseinek. Másolatot kapott a napi jelentésekből a külügyminiszter, a honvédelmi miniszter és a legfőbb ügyész is. ${ }^{18} \mathrm{~A}$ felsorolt intézmények képviselői rendszeresen egyeztettek a jelentések a tájékoztatási feladatokról. A BM irányítása alá tartozó hírszerző és elhárító szolgálatok között intézményesített együttmúködés formáival és a tájékoztatási folyamatok összehangolásával a Kádárkorszak állambiztonsági rendszere - az MNVK-2 helyzetéből fakadó versengő, illetve szektoriális jegyek megőrzése mellett - jelentős mértékben elmozdult a kooperáló modell megvalósításának irányába.

\section{Koordinációs mechanizmusok a magyar nemzetbiztonsági rendszer genezisének időszakában (1989-1995)}

A rendszerváltás folyamatának kibontakozásakor napirendre került az állambiztonsági szervezet megújítása is. A Belügyminisztériumon belül már 1988-ban megkezdődtek a demokratikus átmenettel összhangban lévő szabályozás előkészítő munkálatai. Az 1989 júniusában meginduló Nemzeti Kerekasztal tárgyalásai során az állampárti oldal nem támogatta az ellenzéki javaslatát, amely az állambiztonsági funkciók határozott (a kormányzati irányítás szintjén megvalósuló) elválasztását indítványozta a közbiztonsági, bűnüldöző és igazgatásrendészeti feladatokat ellátó rendőri szervezettől, valamint kezdeményezte a szolgálatok közvetlenül a Minisztertanács alá rendelését. ${ }^{19}$ A Belügyminisztériumban elkészült javaslatok a BM III. Főcsoportfőnökség különböző irányú szervezeti átalakításával számoltak, azonban konszenzusos pontként jelent meg az új „Biztonsági Szolgálat” - mai szóhasználattal élve - polgári nemzetbiztonsági területeinek egységes szakmai irányítása és kormányzati (BM) felügyelete. Az egyes

MÜLLER 1999, 250-251.

A témakört bővebben elemzi RÉvÉsz 2000, 420-478. 
szakterületek közötti koordináció erősítése érdekében több helyen felbukkant a „Vezetési Törzs” vagy „Vezetői Tanács” létrehozásának igénye. ${ }^{20}$

$A z$ „állambiztonsági műhelyekben” előkészített javaslatokat azonban elsodorta az 1990. január 5-én kipattant, később „Duna-gate” néven elhíresült megfigyelési botrány. A megváltozott belpolitikai légkörben garanciális elemként fogalmazódott meg a „túlzott hatalomkoncentrációt” lehetővé tevő egységes állambiztonsági rendszer szétdarabolásának és a nyílt nyomozati jogokkal rendelkező (ennek során akár kényszerintézkedéseket alkalmazó) rendészeti szféráról történő leválasztásának igénye. A különleges titkosszolgálati eszközök és módszerek engedélyezésének átmeneti szabályozásáról szóló 1990. évi X. törvény által adott felhatalmazás alapján a Minisztertanács immár nemcsak a Belügyminisztériumtól elkülönített kormányzati irányítási rendszer mellett foglalt állást, de döntött az egymástól a szakmai vezetés szintjén elváló nemzetbiztonsági szolgálatokról is. A magyar nemzetbiztonsági struktúra szektoriális jellegét az Antall-kormány hivatalba lépését követő intézkedések tovább erősítették. Az új Országgyúlés a politikai rendszer stabilitásának biztosítása - elsősorban a konstruktív bizalmatlansági indítvány intézményével is megerősített kormányfői pozíció védelme - érdekében az 1990. évi LI. törvény elfogadásával a katonai szolgálatokat a honvédelmi miniszter, a polgári szolgálatokat pedig kijelölt tárca nélküli miniszter felügyelete alá helyezte.

Függetlenül attól, hogy a jogalkotó az 1990 elején kialakított normákat ideiglenesnek szánta, a nemzetbiztonsági tevékenységre vonatkozó szabályozás kétharmados parlamenti többséget igénylő jellege, valamint az ezzel nem rendelkező kormánypártok és az ellenzék között kezdettől tapasztalható nagyfokú politikai bizalmatlanság az első ciklusban konzerválta a „négyszolgálatos modellt”. ${ }^{21}$ Az osztott intézményrendszer múködtetéséhez elengedhetetlen kormányzati koordináció biztosítása érdekében az Antall-kormány - a Németh Miklós által vezetett Biztonsági Kollégium funkcióit részben átvéve - 1990 júliusában létrehozta a miniszterelnök által vezetett Nemzetbiztonsági Kabinetet. Ennek elsődleges funkciója a nemzetbiztonsággal kapcsolatos, kormányzati intézkedést igénylő feladatok összehangolása, az aktuális biztonsági kérdések szúkebb körben - az illetékes tárcák vezetőnek jelenlétében történő - megvitatása, összegezve: a kormánydöntések előkészítése lett. A testület személyi összetételéről 1990-től napjainkig a kormányalakítást (vagy-átalakítást) követően kiadott nyilvános kormányhatározatok rendelkeznek, illeszkedve az aktuálisan kialakított szervezeti modellhez. Általános jelleggel elmondható, hogy a nemzetbiztonsági, honvédelmi, külügyi és rendészeti ágazat irányításáért felelős miniszterek mellett

20 Az új „négyszolgálatos modell” felépítését a nemzetbiztonsági feladatok ellátásának átmeneti szabályozásáról szóló 26/1990. (II. 14.) MT rendelet, valamint a nemzetbiztonsági szolgálatok létrehozásáról és működési feltételeiről szóló 3039/1990. számú „minősített” határozat jelölte ki. A magyar titkosszolgálati struktúra rendszerváltás időszakában lezajlott átalakulását átfogóan vizsgálja: BARÁTH 2010.

21 A parlamenti ciklus első éveiben készült tervezetek többségét (köztük az 1991 őszén benyújtott T/1462. számon benyújtott előterjesztést) a szükséges konszenzus hiányában napirendre sem vette az Országgyúlés. 
a kabinetülések állandó meghívottjai között szerepel a kormányzati múködés összehangolásáért, illetve a pénzügyekért felelős tárca vezetője is. ${ }^{22}$

Az már a Nemzetbiztonsági Kabinet felállítását követően érezhetővé vált, hogy az testület által tárgyalt témakörökhöz tartozó, a döntések előkészítését támogató, de egymással párhuzamosan több irányból beérkező információk áttekintése szakértői stáb jelenlétét igényli. A testület titkári feladatát 1990 nyarától ellátó (a polgári nemzetbiztonsági szolgálatokat felügyelő) tárca nélküli miniszter ezért - a honvédelmi tárcánál korábban működő hasonló szervezet tapasztalataira építve - 1993-ban létrehozta a „Nemzetbiztonsági Elemző Munkacsoportot” a Miniszterelnöki Hivatal logisztikai bázisán. Ennek tagjait a szolgálatoktól és a rendvédelmi szervektől vezényelt, az információs munkában tapasztalattal rendelkező munkatársak mellett köztisztviselői státuszban foglalkoztatott szakértők alkották. A munkacsoport tevékenysége 1996 után kiinduló bázisát képezte a polgári nemzetbiztonsági szolgálatokat irányító tárca nélküli miniszter hivatalában megszervezett központi elemző-értékelő és kormányzati tájékoztató tevékenységnek. ${ }^{23}$

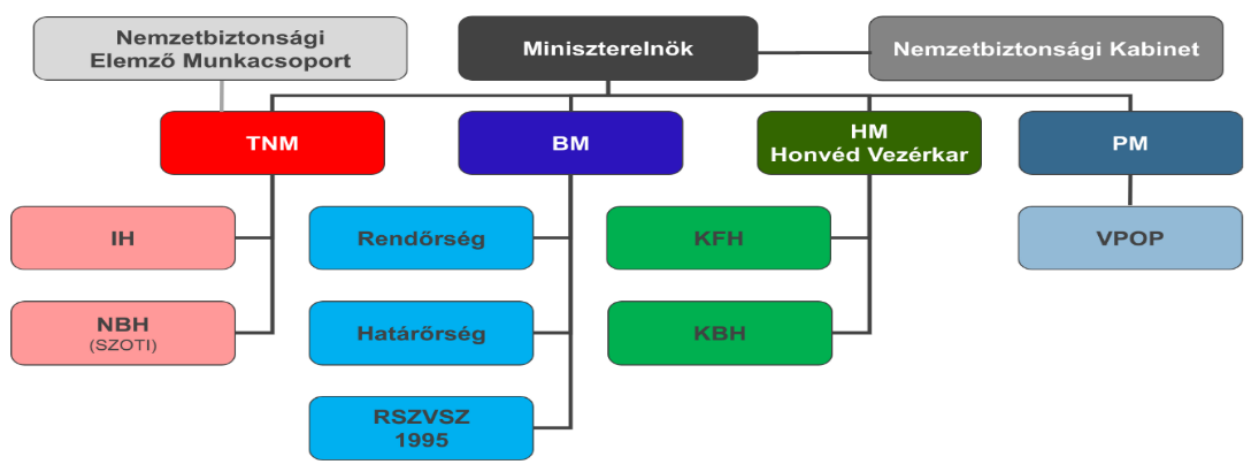

2. ábra

A titkos információgyüjtést folytató szervek kormányzati irányítása (1990-1995)

Forrás: a szerző szerkesztése

Az első ciklusban meghozott intézkedések jól mutatták, hogy kormányzat a hatékony döntéshozatali mechanizmus biztosítása érdekében már a rendszerváltást követően (politikai és szakmai síkon egyaránt) kooperatív intézményi megoldásokkal reagált

22 A testület üléseit 1990 és 1998, valamint 2010 és 2018 között a kormányfő elnökölte. Az első Orbán-kormány hivatali időszakában a vonatkozó kormányhatározat a belügyminisztert, majd 2002 és 2006 között honvédelmi minisztert jelölte ki az ülések vezetésére. 2006 májusától 2007 nyaráig a kabinet üléseit a polgári nemzetbiztonsági szolgálatok irányításáért is felelős Miniszterelnöki Hivatalt vezető miniszter vezette, majd a feladatot 2010-ig az IH, az NBH és az NBSZ irányítását immár tárca nélküli miniszterként ellátó kormánytag vette át. A negyedik Orbán-kormány megalakulását követően kiadott 1243/2018. (V. 22.) Korm. határozat a belügyminisztert bízta meg a kabinet vezetésével, aki az 1/2018. (V. 22.) ME rendelet alapján ellátja a nemzetbiztonságért felelös miniszterelnök-helyettesi feladatkört. Magyar Közlöny, 70. sz. 2018. május 22. A kormányzati szinten koordinált elemző-értékelő tevékenység 1990 utáni intézményi megoldásait elemzi Hetesy 2013, 26. 
a hazai nemzetbiztonsági rendszer 2. ábrán szemléltetett szektoriális, illetve - a költségvetési források felett diszponáló döntéshozók támogatásának elnyerése kapcsán az önálló költségvetési intézményként múködő szolgálatok esetében jelentkező - versengő jellegére.

\section{A szolgálatok tevékenységének összehangolását célzó intézményi megoldások a nemzetbiztonsági törvény megalkotását követő másfél évtizedben (1996-2010)}

A 1994. évi országgyúlési képviselőválasztások után megalakult kormány kétharmados parlamenti többsége - a koalíciós partnerek közötti nézetkülönbségek, valamint a kormányzat energiáit lekötő gazdasági válságkezelés miatt a tervezettnél hoszszabbra nyúlt egyeztetési folyamat végén - megnyitotta az utat a nemzetbiztonsági szolgálatokról szóló 1995. évi CXXV. törvény (Nbtv.) elfogadásához. A tanulmány által vizsgált témakör szempontjából kijelenthető, hogy a jogalkotó egyik oldalról a hazai nemzetbiztonsági struktúra osztott és szektoriális jellegét erősítette meg:

- az „ötszolgálatos modell” - azaz az önálló Nemzetbiztonsági Szakszolgálat jogállami garanciák és a múveleti-technikai képességek koncentrált alkalmazása és fejlesztése okán a szakmai körökben döntően pozitívan értékelt - létrehozásával;

- valamint azzal, hogy a törvény nem tartalmazott a nemzetbiztonsági struktúrát kooperatív irányba elmozdító, a szolgálatok közötti koordinációt támogató intézményi megoldást.

A másik oldalról az Nbtv. nyitva hagyta a kormány számára az elmozdulás lehetőségét együttműködő modell kialakítása felé azzal, hogy:

- a 11. § (2) b) pontja rögzítette a szolgálatokat „irányító” miniszternek a kormány tagjaitól érkező információs igények koordinációjával kapcsolatos feladatkörét;

- a 11. § (6) bekezdése a polgári nemzetbiztonsági szolgálatokat irányító minisztert hatalmazta fel arra, hogy irányítsa az állami szervektől származó, az ország nemzetbiztonságára vonatkozó információk elemzését, értékelését, valamint az e tárgyú döntés-előkészítő munkát;

- valamint azzal, hogy a 77. § (1) c) pontjában felhatalmazást adott a kormánynak, hogy rendeletben állapítsa meg a nemzetbiztonsági szolgálatok és egyéb állami szerv tájékoztató tevékenységének rendjét, valamint a nemzetbiztonsági információk értékelésének, hasznosításának szervezeti kereteit és részletes szabályait. ${ }^{24}$

Az Nbtv. 1996-ban hatályba lépett szövegének a gyakorló szakemberek tevékenységét segítő (a jogszabályi változásokat pótlapokkal sajnos csak az ezredfordulóig követő) komplex kommentárját tartalmazza: DEZSŐ-HAJAS 1998. 
URBÁN ATTILA: A koordinációs folyamatok intézményi hátterének evolúciója...

A jogalkotó a nemzetbiztonsági tevékenység átfogó szabályozását nyújtó, számos elemében mai is hatályos törvény megalkotásával láthatóan a stabilitást helyezte előtérbe, és nem kívánt átfogó intézményi reformot végrehajtani. A polgári nemzetbiztonsági szolgálatok irányításából „történelmi és alkotmányossági okokból kizárt” miniszterek - nemzetközi összevetésben kuriózumnak számító - felsorolásában is rendszerváltás időszakában dominánssá vált garanciális elemek változatlanul hangsúlyos szerepe tükröződött. Az Nbtv. parlamenti vitájában az „ötszolgálatos” modell racionalizálására vonatkozó képviselői felvetések végül 47/1996. (VI. 7.) OGY határozatban öltöttek testet, amely felhívta a kormányt arra, hogy a törvény hatálybalépését követő egy éven belül vizsgálja felül a rendszer müködését, és indokolt esetben tegyen javaslatot a szükséges módosításra. A kormány által az Országgyúlés számára a fenti határozat végrehajtásáról 1997 júniusában beterjesztett jelentésben nem tartotta indokoltnak a hatályos szabályozásban rögzített struktúra korrekcióját. Ezzel együtt a jelentés rögzítette, hogy a szolgálatok feladatrendszerében fellelhető párhuzamosságok és a múveleti munkát támogató technikai eszközök fejlesztése szükségessé teszik az „erőteljesebb koordinációt”. A törvényhozásnak megküldött dokumentum a Nemzetbiztonsági Kabinet döntés-előkészítő funkciójának támogatása kapcsán kitért a polgári nemzetbiztonsági szolgálatokat irányító miniszternek az Nbtv. 11. § (6) bekezdésében meghatározott feladatkörére, illetve arra, hogy ezt a tevékenységet a miniszter „apparátusának” kell támogatnia. ${ }^{25} \mathrm{~A}$ kormány a törvény hatálybalépését követően - élve az Nbtv. 77. § (2) b) pontjában szereplő felhatalmazással - minősített („háromezres”) határozatban jelölte ki a szolgálatok tevékenységének fö irányait, valamint meghatározta az illetékességük és egymással történő együttmúködésük szabályait.

Az Nbtv. elfogadását követő másfél évtizedben mind kormányzati szinten, mind a szakmai, tudományos szféra részéről búvópatakként kerültek időről időre felszínre a magyar nemzetbiztonsági struktúra modernizációjára vonatkozó kezdeményezések és koncepciók. Ezek többsége - az NBSZ integritásának megőrzése mellett - a szolgálatok „funkcionális” (IH-KFH, NBH-KBH) vagy kormányzati irányításközpontú „,szektoriális" (IH-NBH és KFH-KBH) integrációjának lehetőségét vizsgálta. ${ }^{26}$ Mindez az jelzi, hogy az osztott intézményrendszerből fakadó párhuzamosságok csökkentése, illetve felszámolása témakörében született javaslatok középpontjában a szolgálatok szakmai vezetési szinten történő integrálása állt. A kibontakozott diskurzus margóján ezzel párhuzamosan megjelent a koordinációs intézmények fejlesztésének igénye is. Az Nbtv. ez irányú hiányosságát a kortárs elemzések is érintették, többnyire azt a következtetést levonva, hogy a törvényalkotó szándéka szerint a polgári és katonai nemzetbiztonsági szolgálatok tevékenységének összehangolását, illetve az ezért felelős koordinációs intézmény szervezeti kereteit és jogosultságait a mindenkori kormányzat belső mechanizmusához illesztve érdemes kialakítani. ${ }^{27}$

$25 \quad$ A jelentésben szereplő kormányzati álláspont nemzetbiztonsági struktúrára kifejtett hatását bővebben értékeli: KovÁcs-DoBÁK 2017, 183-184.

26 A kérdés vizsgálatának széles szakirodalmi kínálatából - a tanulmány bevezetőjében említett átfogó munkák mellett - kiemelésre érdemes: KÁRPÁTI 2006, 99-101., IZSA 2009, 50-59., valamint HETESY 2011, 21-25.

DEZSŐ-HAJAS 1998, 126 
A törvény hatálybalépését követően, a jogszabály 77. § (1) c) pontjában szereplő felhatalmazás alapján megindult normaalkotási folyamat érzékeny területét képezte, hogy a koordinációs folyamatok fejlesztését a Nemzetbiztonsági Kabinet jogköreinek bővítésével, a testület szervezeti (állandó szakértői) hátterének kialakításával, vagy a kormányzati rendszerbe illesztett új intézmény létrehozásával valósuljon meg. Az Nbtv. 11. § (6) bekezdésében kapott felhatalmazás alapján ez utóbbi megoldás leginkább a polgári nemzetbiztonsági szolgálatokat irányító miniszter környezetében volt elképzelhető. A törvény hatálybalépését követően a miniszter kabinetje a szolgálatok szakértőinek bevonásával megkezdte a nemzet biztonságát érintő információk gyújtésének, értékelésének, elemzésének és a kormányzati tájékoztatás rendjét szabályozó kormányhatározat előkészítését. Az első változatban már 1996-ra elkészült, majd az ezt követő évtizedben többször korrigált tervezetek közös eleme volt:

- a tárca nélküli miniszter kabinetjének/hivatalának intézményi rendjébe illesztett, a szolgálatoknál, rendvédelmi szerveknél és a tárcáknál keletkező nemzetbiztonsági információk egybevetésére és értékelésére épülő kormányzati tájékoztató tevékenységet végző szervezet („Információs Iroda/Központ/ Osztály") létrehozása;

- többcsatornás tájékoztatási rend múködtetése, amelyben a nemzetbiztonsági szolgálatok a megőrzik korábbi (közvetlen) tájékoztatási lehetőségeiket is, azaz: az információikat a kormányzati címzettel párhuzamosan küldik meg a központi elemző szervezetnek;

- valamint a központi elemző szervezet részéről hírigény megfogalmazásának lehetősége a szolgálatok és az érintett tárcák részére.

A nemzetbiztonságot érintő információk integrált elemzését megvalósító szervezetről szóló kormányhatározat kiadására az Nbtv. által adott felhatalmazás ellenére végül nem került sor. A normaalkotási folyamat - az érintett tárcák és a szolgálatok bevonásával lefolytatott egyeztetések során felszínre került, egymással ütköző, jellemzően szektoriális szempontokat előtérbe helyező álláspontok miatt - ugyanis rendre megrekedt a jogszabály-előkészítés fázisában. A polgári nemzetbiztonsági szolgálatokat irányító miniszter már a fenti egyeztetési folyamat elején, 1996-ban a saját hivatalába integrálta a Nemzetbiztonsági Elemző Munkacsoportot. ${ }^{28}$

Az első Orbán-kormány megalakulása után a Miniszterelnöki Hivatal szervezeti rendjén belül hozta létre a védelmi és nemzetbiztonsági ügyekkel foglalkozó politikai államtitkár posztot, amelyet a kormányfő „nemzetbiztonsági főtanácsadójaként” Gyuricza Béla töltött be. Az általa koordinált, az osztott intézményrendszer teljes spektrumán keletkező biztonságpolitikai információkra épülő döntés-előkészítő tevékenység az államtitkár 1999-ben bekövetkezett korai halála, majd a feladatkörének az ezt követő megszüntetése után nem folytatódott.

A kormány - a számára parlamenti többséget biztosító pártok korábbi, ellenzéki pozícióban képviselt álláspontjával összhangban - az ezredfordulón szakpolitikai egyeztetést kezdeményezett a hazai nemzetbiztonsági rendszer felülvizsgálatáról. A szervezeti változtatások megalapozását célzó, 2000 októberében megtartott nemzetközi 
URBÁN ATTILA: A koordinációs folyamatok intézményi hátterének evolúciója...

konferenciára - a brit, az olasz, a német, a francia és a magyar nemzetbiztonsági igazgatás vezető beosztású képviselőivel és a hazai szakemberekkel párhuzamosan - meghívást kaptak az ellenzéki pártok képviselői és szakértői is. Az utóbbi döntés a struktúra lehetséges korszerüsítésének körültekintő (konszenzusos) előkészítésére irányuló kormányzati szándékot is jelezte, tekintettel arra, hogy az első Orbán-kormány nem rendelkezett az Nbtv. módosításához szükséges kétharmados parlamenti többséggel. A tanácskozás homlokterében természetesen az „ötszolgálatos modell” lehetséges meghaladása állt, összhangban az euroatlanti térséget érintő új típusú biztonsági kihívásokkal, valamint az NATO- és (a közelgő) EU-tagságból fakadó feladatokkal. Mint kiderült, ennek megvalósítását a kormánypárti és az ellenzéki előadók különböző irányban képzelték el. A fentiekkel párhuzamosan azonban szinte minden előadó érintette a koordinációs folyamatok fejlesztésével kapcsolatos kérdéseket. Ezzel egyúttal többen reflektáltak a polgári nemzetbiztonsági szolgálatokat irányító miniszter nyitóelőadásában, a hazai rendszerben „történelmi okokra visszavezethető” párhuzamosságok negatív hatásait érintő kijelentésekre. A rendezvényen elhangzott, a „kooperatív modell” működését érintően több előadásban is megjelenő megállapítások - a tanulmány belső arányaihoz igazított vázlatos terjedelemben - az alábbiakban összegezhetők:

- Az osztott intézményrendszerben fellelhető felesleges párhuzamosságokat jelentős mértékben csökkentheti, ha a kormányzati hírigényeket az ezek összesítésért felelős tárcák vezetői egymással egyeztetve fogalmazzák meg.

- A nemzetbiztonsági tevékenység minden ágazatát lefedő, a középtávú elvárásokat és az ezekkel összhangban lévő fejlesztési irányokat kijelölő kormányzati stratégiai dokumentum megalkotása érdemben segítheti a rendelkezésre álló múveleti erőforrások koordinált felhasználását.

- A hatékony döntési folyamatok támogatása és a kormányzat részéről megfogalmazott feladatok összehangolt végrehajtása („,koordinált és aktualizált hírigények által vezérelt múveleti munka”) érdekében szükséges (a Nemzetbiztonsági Kabinet vagy a tárca nélküli miniszter mellett) egy állandó „elemző és tanácsadó/tájékoztató” szervezet felállítása. Felmerült, hogy koordinációs stábokat érdemes célzott körben - kül- és biztonságpolitikai, valamint a belbiztonsági-bűnügyi területen - múködtetni.

- A kormány számára releváns információk összehangolását segítheti, ha a miniszterelnök tájékoztatása (különleges esetek kivételével) a koordinációért felelős kijelölt személyen - a Nemzetbiztonsági Kabinet elnökén, vagy a kormányfő „nemzetbiztonsági főtanácsadóján” - keresztül valósul meg.

- A polgári elhárítás és a rendészeti szervek közös „szakminiszter” (azaz a BM) irányítása alá helyezése - a szinergiák jobb kihasználásával - mindkét ágazatban hatékonyságnövekedést eredményezhet.

- Az átfedéseket tartalmazó törvényi feladatszabás és a titkosszolgálati eszközök alkalmazására jogosult szervek bővülése miatt a nemzetbiztonsági koordinációs folyamatok fejlesztésénél kalkulálni kell a rendészeti tevékenység releváns területeivel is. ${ }^{29}$

$29 \quad$ A rendezvényen a nemzetbiztonsági struktúra átalakításával kapcsolatban megfogalmazott elképzeléseket - parlamenti pártok szerinti bontásban is - értékeli: HETESY 2011, 23. 
A kormányzat a konferenciát követően, a parlamenti pártok eltérő álláspontja miatt nem nyújtott be a nemzetbiztonsági struktúra módosítására irányuló előterjesztést az Országgyűlés elé. Ettől függetlenül a fenti javaslatok - a 2010 után megvalósult intézményi megoldások tükrében - figyelmet érdemelnek. Különösen nemzetbiztonsági és rendészeti tevékenység összehangolásának kérdéskörére, amely nemcsak az Nbtv. és a rendőrségről szóló 1994. évi XXXIV. törvény átfedései, de Magyarország 1990-es években leromlott közbiztonsági viszonyai - különösen a közterületen elkövetett merényletek - kapcsán a belpolitika napirendjére került.

A kormány több európai, ezen belül elsősorban a brit „kooperáló” modell tanulmányozása után, nem sokkal a fent tárgyalt konferencia megrendezése után létrehozta a Szervezett Bünözés Elleni Koordinációs Központot (SZBKK). Az első hazai „információfúziós” intézmény titkosszolgálati eszközök alkalmazására jogosult szervektől érkező adatok alapján végzett elemző-értékelő és tájékoztató tevékenységet. Feladatkörében nemcsak a kijelölt kormányzati döntéshozók, de „visszatájékoztató” (koordinációs) munkája keretében az adatszolgáltató szervek múveleti tevékenységének támogatása is szerepelt. ${ }^{30}$ Az önálló titkos adatszerzést nem végző SZBKK állományát az együttműködő nemzetbiztonsági és rendészeti szervek vezényelt munkatársai alkották. ${ }^{31}$ A szervezet alaptevékenysége az ezredforduló után - alkalmazkodva biztonságpolitikai környezet változásához - a terrorizmus elleni küzdelem területén is egyre markánsabbá vált, majd a 2000-es évek végén a politikai extrémizmushoz kapcsolódó bűncselekmények elleni fellépés támogatásában bővültek a feladatai. Tekintettel azonban arra, hogy a SZBKK múködése döntően a számára megküldött adatokra támaszkodott, tevékenységének hatékonysága mindvégig erősen függött a nemzetbiztonsági és bünüldöző szervek együttmúködési hajlandóságától. ${ }^{32}$

A koordináció intézményesített formáinak fejlesztését nemcsak a szervezett bünözés egyre agresszívabb formái, de titkosszolgálati eszközök alkalmazására jogosult szervek számának jelentős növekedés is indokolta. A nemzetbiztonsági szolgálatokon és a rendőrségen kívül titkos információgyűjtésre 1995 és 2001 között még további öt állami szerv, a rendvédelmi szervek belső bűnmegelőzését végző Rendvédelmi Szervek Védelmi Szolgálata (RSZVSZ), a Vám- és Pénzügyőrség Országos Parancsnoksága (VPOP), a határőrség, ${ }^{33}$ az Ügyészségi Nyomozó Hivatal, valamint az APEH Nyomozó Hatósága kapott jogszabályi felhatalmazást. Utóbbitól az Alkotmánybíróság 2001. július 9-én meghozott határozatában - alkotmányjogi aggályokra hivatkozva 2002 tavaszi határidővel megvonta ezt a jogosultságot.

A 2002-ben bekövetkezett kormányváltás jelentős változásokat eredményezett a polgári nemzetbiztonsági igazgatás területén. A kormányon belül megszüntetett tárca nélküli miniszteri beosztásra tekintettel a polgári nemzetbiztonsági szolgálatok irányítási jogkörét a Miniszterelnöki Hivatalt vezető miniszter (MeH VM) kapta meg.

30 A működését szabályozó 2000. CXXVI. törvény parlamenti vitájában a polgári nemzetbiztonsági szolgálatokat irányító, egyúttal az előterjesztést beterjesztő miniszter kiemelte, hogy a kormányzat várakozásai szerint a SZBKK felállításával kiküszöbölhető a titkos adatszerzésre jogosult szervek munkájában korábban tapasztalható párhuzamosságok. Parlamenti jegyzőkönyvek, 2000. szeptember 27.

31 A SZBKK múködését részletesen elemezte BÁLINT 2012.

32 KovÁcs-Dobák 2017, 185.

33 A határőrség az Európai Unió schengeni térségéhez történő csatlakozásunkkal párhuzamosan, 2008. január 1-jével integrálódott a rendőrség szervezetébe. 
URBÁN ATTILA: A koordinációs folyamatok intézményi hátterének evolúciója...

Tekintettel a kormányzati munka koordinációjában jelentkező szerteágazó feladatkörére, a 1093/2002. (VI. 8.) Korm. határozat a polgári nemzetbiztonsági szolgálatok kormányzati irányításának napi feladatait, ezzel tevékenységük politikai szintű koordinációját a miniszter irányító feladataiban közremúködő politikai államtitkárához delegálta. A tárca nélküli miniszter korábbi Hivatala - 2006 tavaszáig az államtitkár irányítása alatt - MeH Nemzetbiztonsági Iroda (NBI) néven működött tovább. Ennek személyi állománya továbbra is minisztériumi köztisztviselőkből és a szolgálatoktól berendelt hivatásos állományból tevődött össze. A polgári nemzetbiztonsági tevékenység területén koordinációs tevékenységet támogató közigazgatási szervként a szolgálatok vonatkozásában nem rendelkezett közvetlen irányítási jogkörökkel. Az NBI „tanácsadó és információs” szakterülete - a tárcáktól begyújtött hírigények koordinálásával - közremúködött a nemzetbiztonsági szolgálatok időszerű feladatainak meghatározásában és azok végrehajtásának figyelemmel kísérésében. Emellett részt vett a kormányzat nemzetbiztonsági kérdésekkel kapcsolatos döntései előkészítésének támogatásában. Ennek során a szolgálatoktól és a biztonságpolitikai szempontból fontos tárcáktól érkező információk felhasználásával tájékoztatókat, összefoglaló elemzéseket készített a kormány tagjai számára, illetve gondoskodott az Országgyúlés Nemzetbiztonsági Bizottságának tájékoztatásáról is. Tekintettel arra, hogy a honvédelmi tárca vezetőjét váltva, 2006 nyarától a Miniszterelnöki Hivatalt vezető miniszter elnökölte a Nemzetbiztonsági Kabinet üléseit, testület titkársági feladatait (2010 tavaszáig) az NBI látta el. ${ }^{34}$

2006 nyarától hangsúlyosabbá tette az NBI vezetőjének koordinációs szerepét, hogy a második Gyurcsány-kormány szerkezetét meghatározó 2006. évi LVII. törvény megszüntette a polgári nemzetbiztonsági szolgálatok irányításában közremúködő politikai államtitkári posztot. Az NBI bázisán megvalósuló intézményesített együttmúködés területét vertikálisan tovább növelte, hogy a 160/2006. (VII. 28.) Korm. rendelet a MeH VM alatt, a kormányzati irányítás szintjén integrálta a polgári nemzetbiztonsági szolgálatokat, a Nemzeti Biztonsági Felügyeletet, a Szervezet Bűnözés Elleni Koordinációs Központot és a Rendvédelmi Szervek Védelmi Szolgálatát. 2007 júliusában a kormány ismét létrehozta a polgári nemzetbiztonsági szolgálatokat irányító tárca nélküli miniszteri, illetve az irányítási feladatokban közremúködő államtitkári posztot. A nemzetbiztonsági tevékenység „polgári” és katonai területe közötti koordináció fejlesztésének kormányzati igényére utalt, hogy ez utóbbi posztot 2007 és 2010 között a HM korábbi államtitkára töltötte be.

Az ezredforduló első éveiben - különösen az Egyesült Államokat 2001 szeptemberében ért összehangolt terrortámadás, majd az isztambuli, madridi és londoni merényletek kapcsán - Magyarország biztonsági helyzetében is felértékelődött a terrorizmus elleni küzdelem szerepe. A partnerszolgálati együttműködést támogató multilaterális fórumos és nemzetközi adatbázisok számának bővülése mellett az euroatlanti térségben teret nyertek a nemzetbiztonsági szervezetek tevékenységének korábbiaknál hatékonyabb összehangolására létrejött szervezetek. ${ }^{35}$ Ez a nemzetközi trend részben hazánkban is érvényesült, amikor a Nemzetbiztonsági Kabinetjének

Az NBI feladatrendszeréről és szervezeti rendjéről áttekintést nyújt: SABJANICS 2007. KovÁcS-DOBÁK 2017, 186. 
döntése alapján 2003-ban megkezdte működését a Terrorellenes Koordináló Bizottság (TKB) a Nemzetbiztonsági Hivatal bázisán. A megalakulását követő időszakban hetente, majd később az országot érintő fenyegetettség szintjének függvényében ülésező szervezet fő feladatát a nemzetbiztonsági szolgálatok és rendvédelmi szervek által megszerzett információk gyors és összehangolt elemzése, a kormányzat döntéseit támogató tájékoztatás, valamint a múveleti tevékenységét segítő koordináció támogatása jelentette. ${ }^{36}$

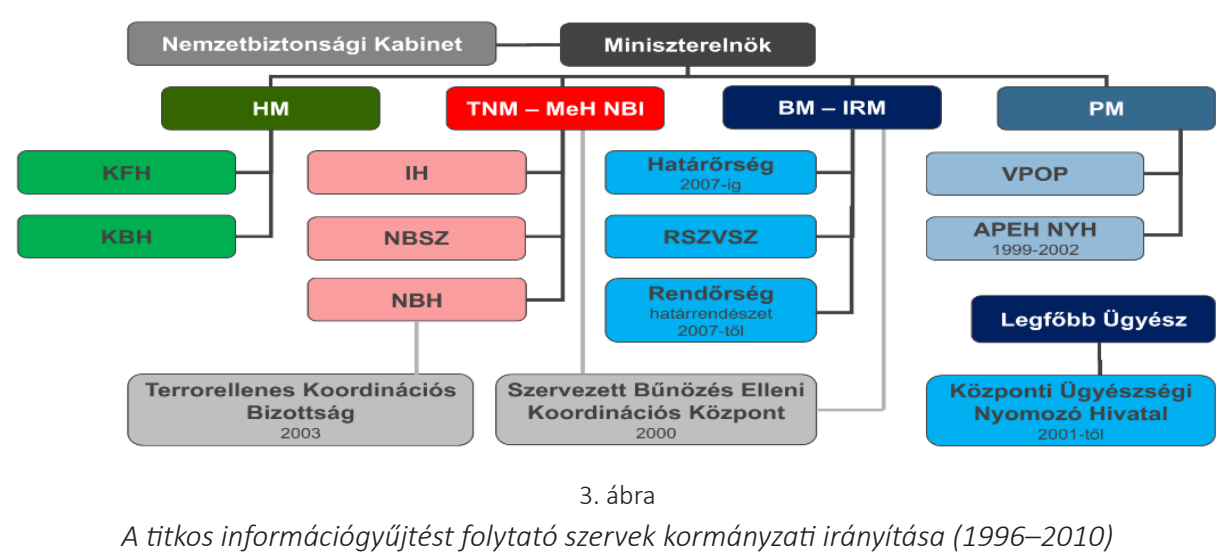

Forrás: a szerző szerkesztése

A 2006-ban megalakult második Gyurcsány-kormány - elsősorban költségvetési szempontok alapján - a „háromszolgálatos” modell irányába történő elmozdulást kezdeményező 2118/2006. (VI. 30) Korm. határozat kiadásával napirendre tűzte a 3. ábrán szemléltetett hazai nemzetbiztonsági intézményrendszer átalakítását. A Miniszterelnöki Hivatalt vezető miniszter irányításával, MeH NBI bázisán kidolgozott javaslat „funkcionális” (feladatközpontú) irányai megjelentek a 2010/2007. (I. 30.) Korm. határozat szövegében is. A koncepciót előkészítő szakértői bizottságok figyelme a kormány elvárásainak megfelelően elsősorban a szolgálatok számának lehetséges csökkentésére, azaz a nemzetbiztonsági tevékenység szakmai vezetési szinten történő integrálására irányult. Mindez azt is jelezte, hogy a kormányzati szinten korábban kialakított koordinációs intézmények a döntéshozók értékelése szerint nem voltak képesek a hazai osztott intézményi modellben meglévő szektoriális és versengő elemek hatékony kezelésére. Az ezekből fakadó párhuzamosságok költségvonzatainak

36 A kormány a 2239/2005. (X. 28.) határozatában szabályozta a Terrorellenes Koordinációs Bizottság működését. A szervezet működésének és a hazai nemzetbiztonsági közösségbe való beilleszkedésének bővebb áttekintését nyújtja: Tüттő 2007. 
csökkentése - az ország instabillá vált gazdasági helyzetében - immár cselekvésre késztette a kormányzatot. ${ }^{37}$

A reformkísérlet időben egybe esett az Állami Számvevőszék (a továbbiakban: ÁSZ) polgári nemzetbiztonsági szolgálatokat érintő időszakos vizsgálatával. Az ennek megállapításait is tartalmazó éves jelentésében az ÁSZ - az összevonási koncepcióban szereplő megoldást „szakmai kérdésnek” minősítve - nem foglalt állást abban, hogy a szolgálatok hosszabb távon milyen struktúrában múködhetnek a leghatékonyabban. Ezzel együtt felhívta az Országgyúlés figyelmét arra, hogy az intézményrendszer első számú indítékaként hangoztatott párhuzamosságok kiküszöbölésének a feladatmegosztás, a humán és anyagi erőforrás-felhasználás, valamint a technikai fejlesztés területén egyaránt hatékony eszköz lehet megfelelő koordináció. ${ }^{38}$

Az összevonási koncepció a szolgálatokat irányító tárcák eltérő álláspontja miatt 2007-ben lekerült a kormány napirendjéről, az ÁSZ fenti megállapítását pedig 2010-ig nem követték a koordináció intézményi hátterének fejlesztésére irányuló kormányzati lépések. Az osztott intézményrendszerből fakadó negatív hatások azonban ezt követően is érezhetők maradtak. A 2009-ben hivatalba lépett Bajnai-kormány tárca nélkül minisztere - a Nemzetbiztonsági Kabinet tagjainak igényére hivatkozva - az irányítása alá tartozó SZBKK és a polgári nemzetbiztonsági szolgálatok bevonásával közös, a kormányzati hírigények kiemelt témaköreinek távlati perspektíváit is értékelő jelentési rendszer kialakítását kezdeményezte a MeH NBI koordinációjával. A nemzetbiztonsági információk hatékonyabb integrációjának szükségességére a 2008 után faji indítatásból elkövetett gyilkosságok kapcsán végrehajtott hatósági intézkedéseket vizsgáló parlamenti bizottság is rámutatott. ${ }^{39}$

\title{
A kormányzati irányítás 2010 után végrehajtott átfogó reformjának és az információfúziós folyamatok kibontakozásának nemzetbiztonsági koordinációt érintő intézményi vonatkozásai
}

\begin{abstract}
A 2010. május 28-án létrejött, az Nbtv. módosításához a szükséges parlamenti többséggel rendelkező második Orbán-kormány a hazai nemzetbiztonsági struktúrát érintő alapvető változtatásokat hajtott végre. Az átalakítások első hulláma az igazgatási rendszerre fókuszált: a 2010. évi XLII. törvény, illetve az erre épülő 212/2010. (VII. 1) Korm. rendelet alapján az IH a külügyminiszter, az NBSZ és Alkotmányvédelmi Hivatal $(\mathrm{AH})$ - az NBH jogutódja - az újjászervezett belügyi tárca vezetőjének irányítása alá

$37 \quad \mathrm{Az}$ „„̈̈tszolgálatos modellben” fellelhető felesleges párhuzamosságok csökkentésének célkitúzését a költségvetési megtakarítások szándékával összekapcsoló, végül a kormányzaton belül a honvédelmi tárca ellenállásán elbukó reformkísérletet - a tanulmány bevezetőjében említett átfogó munkák mellett - különböző aspektusból értékeli: IZSA 2009, HETESY 2011, SZENTGÁLI 2015 és KovÁcs 2019.

38 Jelentés az Állami Számvevőszék 2007. évi tevékenységéről. (2018. április) 91-92. https://asz.hu/storage/ files/files/tajekoztato_az_allami_szamvevoszek_eves_tevekenysegerol/0803j000.pdf?ctid=271 (A letöltés dátuma: 2019. 10. 25.)

39 KovÁcS-DOBÁK 2017, 188.
\end{abstract}


került. A fenti megoldás - az Nbtv. korábbi 10. § (2) bekezdésében szereplő korlátozás kiiktatásával - az általános európai (a polgári hírszerzés új helyzete kapcsán főként a brit) megoldásra emlékeztető gyakorlatot követve, a kül- és biztonságpolitika területén meghatározó szakminisztereket helyezte irányítói szerepkörbe. Az átalakítás egyik oldalról megvalósította a nemzetbiztonsági és a rendvédelmi (múveleti) kapacitások integrációját a BM szervezeti rendjében. ${ }^{40}$ Ezzel párhuzamosan azonban tovább erősödött a magyar nemzetbiztonsági igazgatás osztott jellege, hiszen a szolgálatok kormányzati irányítási feladatai immár - a korábbi kettő helyett - három minisztérium között oszlottak meg. ${ }^{41}$

A fenti döntésnek megfelelően a MeH NBI által 2010 nyara előtt ellátott koordinációs, illetve közigazgatási feladatokat immár a külügyi és a belügyi tárcánál kellett megszervezni, a KüM esetében a parlamenti államtitkár, a BM-nél pedig a Miniszteri Kabinet támogatásával. A miniszteri irányítás új rendszere az elmúlt évtizedben a belügyminiszter vonatkozásában maradt tartós, akinek a polgári nemzetbiztonsági szolgálatok (AH és NBSZ), valamint a SZBKK irányításával kapcsolatos feladatainak ellátásában 2014 után a Rendészeti Államtitkárság működött közre. Ugyanebben az évben jött létre a BM Rendészeti Informáicós Főosztály (RENFO), amely a miniszter irányítása alatt álló szervek információira épülő tájékoztató tevékenységet látott el, valamint közremúködött hírigények koordinációjában. ${ }^{42}$

A polgári hírszerzés kormányzati irányításában viszont már 2012-ben változás történt, amikor a „német modellt” követve ez a feladat átkerült a Miniszterelnökségre (ME). Itt a közigazgatási feladatok, illetve a beérkező hírszerző jelentések koordinált előkészítését végző „törzsként” létrejött a Nemzetbiztonsági Iroda. Az IH napi kormányzati irányításának napi feladatait a 2012. évi XCVI. törvény alapján kezdetben - az irányítást formailag magához vonó kormányfőtől az Nbtv. által delegálható területeken - az intézményt vezető államtitkár, majd a harmadik Orbán-kormány időszakában, a 152/2014. (VI. 6.) Korm. rendelet alapján (immár teljes hatáskörrel) a ME szervezetét vezető miniszter látta el. ${ }^{43}$

A nemzetbiztonsági igazgatásban 2010-ben végrehajtott változások érintették a Nemzetbiztonsági Kabinet működését is, amelynek üléseit 2018 nyaráig ismét a kormányfő vezette. A korábbi időszakban felmerült javaslatok alapján, a kormányzati döntések hatékonyabb szakmai szintú előkészítése és a feladtok összkormányzati szinten koordinált elosztása érdekében a kormány 2011 őszén létrehozta

$40 \quad$ Ennek a folyamatnak intézményi oldalról leglátványosabb eredménye Terrorelhárítási Központ (TEK) létrejötte volt. A 295/2010. (XII. 22.) Korm. rendelet alapján új szervezetbe integrálódtak a polgári elhárítás $(\mathrm{AH})$ és rendőrség terrorfelderítési és -elhárítási részlegei. A TEK átvette a TKB működtetésével kapcsolatos koordinációs feladatokat is.

41 A 2010 után végrehajtott intézmény átalakításokat, illetve ezek hatásait - a tanulmány bevezetőjében említett átfogó munkák mellett - bővebben elemzi: HETESY 2011, SZENTGÁLI 2015 és KovÁcs 2019.

42 15/2014. (IX. 5.) BM utasítása a Belügyminisztérium Szervezeti és Működési Szabályzatáról [31. § (2) bekezdés].

432012 júliusában, a Nemzetbiztonsági Bizottság előtti meghallgatásán a külügyminiszter az irányítási rendszer megváltozása kapcsán felhívta a figyelmet a hírszerző és a külügyi szakterület között a közös irányítás alatt kialakult szinergiák megőrzésének és a párhuzamosan keletkező információk koordinációjának fontosságára. Közel két hónappal később, a ME vezető államtitkára ugyanezen a fórumon elsősorban az országot érintő új (főként pénzügyi-gazdasági) kihívásokra való gyorsabb reagálás igényével indokolta, hogy az IH irányítását közvetlenül a miniszterelnök környezetébe helyezte át a kormányzat. Forrás: NBB üléseinek jegyzőkönyvei (2012. július 3., 18-20., 2012. szeptember 11., 10.) 
a Nemzetbiztonsági Munkacsoportot (a továbbiakban: NBMCS). A kabinet munkáját támogató, megalakulása után 2018 nyaráig a belügyi és a honvédelmi tárca vezetőjének közös vezetése alatt múködő testület ülésein a szolgálatok főigazgatói mellett jelen vannak a rendvédelmi szervek országos parancsnokai is. ${ }^{44}$ Az NBMCS múködése immár intézményesített formában, a korábbiaknál szélesebb körben lehetővé tette a testület napirendjére kerülő kérdésekben ügyhöz kötött műveleti, elemzői, valamint fejlesztési együttmúködés megvalósítását.

Az NBMCS megalakításával párhuzamosan a kormányzat napirendjére tǔzte az osztott nemzetbiztonsági intézményrendszer átfogó, kooperatív irányba történő átalakítását. A nagyobbik kormánypárt által korábban támogatott „funkcionális” összevonás, azaz egységes hírszerző (IH-KFH) és biztonsági ( $\mathrm{AH}-\mathrm{KBH})$ szolgálat létrehozása helyett a struktúra módosításának szándéka az alábbi irányokban bontakozott ki:

- a katonai nemzetbiztonsági szolgálatok egységes szakmai vezetés alatti integrációja (a KFH és KBH összevonásával), a kormányzati irányítás módosítása nélkül (HM),

- a polgári nemzetbiztonsági szolgálatok közös kormányzati irányítási rendjének kialakítása (az IH belügyminiszter alá rendelésével), valamint

- a hazai nemzetbiztonsági és rendvédelmi szervek múveleti tevékenysége során keletkező, illetve a nemzeti adatbázisokban elérhető információk felhasználásával központi elemző-értékelő, valamint az erre épülő koordinált kormányzati tájékoztatást végző (nemzetbiztonsági szolgálatként működő, de önálló titkos információszerzésre nem jogosult) információfúziós szervezet létrehozása. ${ }^{45}$

A kormány kétharmados parlamenti többsége ellenére, a szolgálatokat irányító tárcák egymástól eltérő álláspontja miatt 2012. január 1-től csak a Katonai Nemzetbiztonsági Hivatal (a továbbiakban: KNBSZ) létrehozása ${ }^{46}$ valósult meg. A Nemzeti Információs és Bűnügyi Elemző Központ (NIBEK) létrehozását célzó javaslat kapcsán a parlamenti vitában, illetve a közéleti nyilvánosság fórumain - a szervezet adatbázisokhoz való közvetlen hozzáférése és adatkezelési jogosultságai kapcsán megfogalmazott alapjogi dilemmák mellett - ismét felbukkantak a szolgálatok független elemző-értékelő és döntéshozókat közvetlenül elérő tájékoztató tevékenységét, illetve a szektoriális tárcaálláspontokat preferáló megközelítések. Jellemzően ez utóbbi szempontok jelentek meg azokban kormánypárti képviselők (köztük a polgári nemzetbiztonsági szolgálatokat korábban irányító házelnök) által benyújtott módosító javaslatokban, amelyeket az Országgyúlés többsége a BM eredeti előterjesztésével szemben támogatott. ${ }^{47}$

A 2014-2018 közötti parlamenti ciklus első felében Magyarország geopolitikai környezetében megerősödött biztonsági kihívásokra (elsősorban a tömeges migrációra

44 1308/2011. (IX. 6.) Korm. határozat a Nemzetbiztonsági Kabinetről.

45 A BM által november 20-án beterjesztett T/5004. számú törvényjavaslat a SZBKK jogosítványainak kiterjesztésével - amerikai és brit információfúziós példákra hivatkozva - kívánt kialakítani a hírigények meghatározásától a kormányzati visszacsatolásokig terjedő „hírszerzési ciklus” működését koordináló szervezetet. KovÁcs 2019

46 2011. évi CLXXI. törvény 1-2. §.

47 Kövér László házelnök módosító javaslata az egyes rendvédelmi tárgyú törvények módosításáról, valamint az azzal összefüggő további törvényjavaslatokról. 2011. november 30. Lásd: www.parlament.hu/ irom39/05004/05004-0022.pdf (A letöltés dátuma: 2019. 11. 13.) 
és az ismét növekvő európai terrorfenyegetésre) reagálva a kormányzat ismét napirendjére vette a nemzetbiztonsági és a rendvédelmi szférán belüli intézményesített koordináció fejlesztését. Az 1988/2015. (XII. 28.) Korm. határozat alapján a belügyminiszter vezetésével tárcaközi munkacsoport jött létre a Magyarországot érintő biztonsági kihívások hatékony kezelését - kiemelten a szolgálatok és a bünüldöző szervek eredményes felderítési képességének fejlesztését - biztosító intézkedések előkészítése érdekében. Ezek körében a belügyi tárca aktualizálta az információfúziós központ létrehozására vonatkozó 2011-es koncepcióját, amelyhez ezúttal nem párosult a polgári hírszerzés és elhárítás közös kormányzati irányítására vonatkozó javaslat. ${ }^{48}$

Az előterjesztés hazai nemzetbiztonsági rendszer kooperáló jellegének erősítését célzó szövegrészei hasonló utat jártak be, mint a 2011-es NIBEK-koncepció. A belügyi igazgatáson kívül álló nemzetbiztonsági szolgálatokat irányító tárcák (a ME és a HM) vezetői ezúttal is módosító javaslatokkal éltek a parlamenti vita során annak érdekében, hogy a polgári hírszerzés és a KNBSZ megőrizhesse az új „fúziós központtól” fizikailag elkülönülő információs rendszerét (adatbázisát), önálló elemző-értékelő képességeit, valamint a döntéshozók közvetlen tájékoztatásának közvetlen lehetőségét.

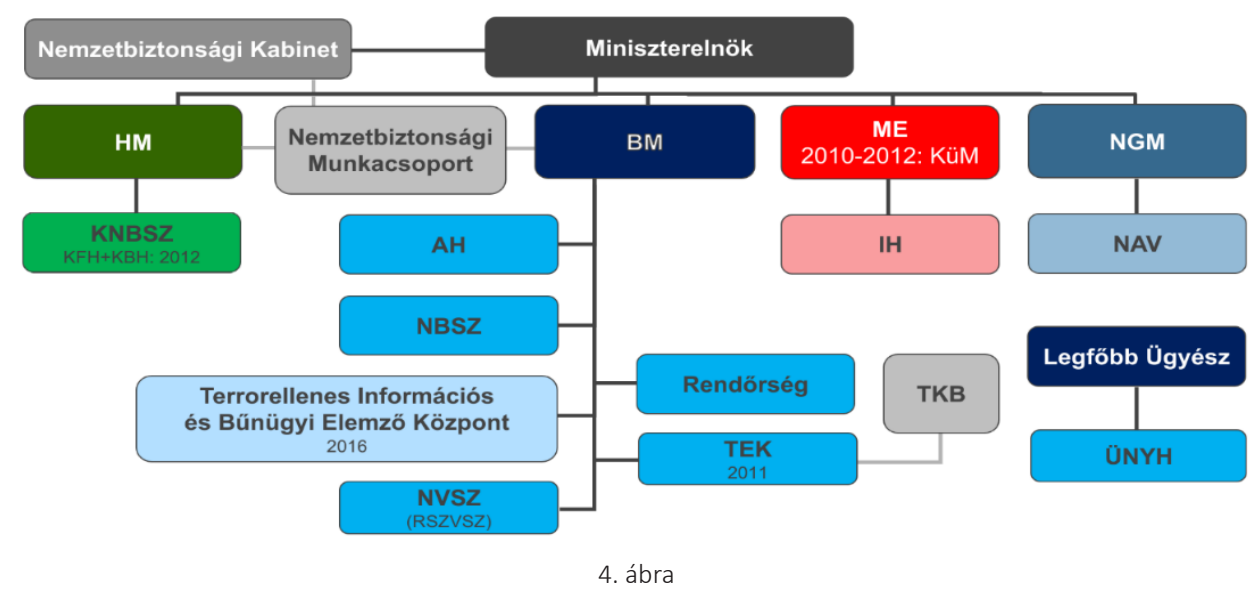

A titkos információgyüjtést folytató szervek kormányzati irányítása (2010-2018)

Forrás: a szerző szerkesztése

A terrorizmus elleni fellépéssel összefüggő egyes törvények módosításáról szóló 2016. évi LXIX. törvény által létrehozott Terrorelhárítási Információs és Bünügyi Elemző Központ (TIBEK) a 4. ábrán látható módon illeszkedett be a hazai nemzetbiztonsági

$48 \quad$ A BM által kidolgozott, T/10307. számú törvényjavaslat szövegéről megindult egyeztetésekbe bekapcsolódtak ellenzéki parlamenti pártok is, tekintettel arra, hogy kormány aktuálisan nem rendelkezett kétharmados többséggel az Országgyúlésben. Az ellenzéki pártok többsége - az általuk felvetett, döntően alapjogi (köztük adatkezelési), valamint általuk „politikai” kérdéseket érintő (kiemelten a Nemzetbiztonsági Kabinet és az NBMCS TIBEK adatbázishoz való közvetlen hozzáférését blokkoló) - módosítások átvezetése után támogatta az előterjesztést. A parlamenti pártok álláspontját tükröző vezérszónoki felszólalásokat közli: Országgyúlési Napló, 2014-2018. országgyúlési ciklus. Budapest, 2016. április 27., szerda 146. szám 23991-24033. 
és rendvédelmi struktúrába. Az SZBKK és a REINFO bázisán megalakult információfúziós szerv elsődleges feladata a hozzá beérkező műveleti adatok értékelése, a kormányzat számára készülő (döntés-előkészítő) tájékoztatók összeállítása, valamint az együttmúködő szervek támogatása a múveleti tevékenységüket támogató adatok és elemzések megküldésével. A jogalkotó a TIBEK feladatkörébe utalta a belügyminiszteri irányítás alatt álló nemzetbiztonsági és rendvédelmi szervek számára szóló hírigények és az időszerű feladatok meghatározásának koordinálását. Az Nbtv. hatálya alá tartozó többi szolgálattal szemben a TIBEK nem rendelkezik titkos információgyújtési jogkörrel, állománya pedig a vele együttmúködő társszervektől vezényelt munkatársak alkotják. ${ }^{49}$

Az Nbtv. módosítását maga után vonó 2016. évi LXIX. törvény elfogadása egyértelműen kooperatív irányba tolta el a hazai intézményrendszert. Az elmozdulás mértékét végül a ME és a HM álláspontjának érvényre jutása határozta meg. Ennek középpontjában az állt, hogy a rendészeti és belső biztonsági körben keletkezett múveleti adatok összevont elemzéséről célszerú leválasztani az IH és a KNBSZ által megszerzett múveleti információk hasznosítását, tekintettel azok külpolitikai és katonai jellegére (azaz: a rendészeti információkkal való korlátozott összevethetőségére). Az információfúziós folyamatok kibontakozása 2016 nyara után elsősorban a BM irányítása alá tartozó nemzetbiztonsági és rendvédelmi szervek múködési területére korlátozódott. A TIBEK tevékenységét a szervezet megalakulása után az IH és a KNBSZ elsősorban belbiztonsági, kiemelten a szervezett bünözés és terrorizmus elleni küzdelemben általuk relevánsnak értékelt múveleti értesüléseik megküldésével, valamint a fúziós központ hozzájuk beérkező hírigényeinek teljesítésével támogatja.

A magyar nemzetbiztonsági igazgatás jelen tanulmány megszületésekor érvényes szerkezete az 2018. évi országgyúlési képviselőválasztásokat követő hónapokban alakult ki. A 94/2018. (V. 22.) Korm. rendelet, illetve a 1243/2018. (V. 22.) Korm. határozat kiadása 8 év után változást hozott a nemzetbiztonsági és rendvédelmi tevékenység összkormányzati szintű koordinációját ellátó Nemzetbiztonsági Kabinet vezetésében. A testület üléseit - immár a miniszterelnök nemzetbiztonságért felelős helyetteseként - a belügyminiszter vezeti. ${ }^{50} \mathrm{~A}$ belügyi tárca szerepe hangsúlyosabbá vált a kabinetnek szakmai háttértámogatást nyújtó NBMCS múködtetésében is, amelynek üléseit 2010 nyarától a polgári nemzetbiztonsági szolgálatok (köztük a TIBEK) és a rendvédelmi szervek irányításában is közremúködő BM Közbiztonsági Főigazgató ${ }^{51}$ elnökli.

A TIBEK múködéséről bővebb tájékoztatást nyújt: BÁLINT 2017, 243-255.

A kabinet osztott intézményrendszerben betöltött koordinációs szerepének fontosságára a nemzetbiztonsági miniszterelnök-helyettes kinevezési előtti parlamenti meghallgatásán külön felhívta a képviselők figyelmét. Jegyzőkönyv az Országgyűlés Honvédelmi és rendészeti bizottságának, valamint Nemzetbiztonsági bizottságának az Országgyúlés Irodaháza III. tárgyalójában 2018. május 14-én, hétfőn 13 óra 30 perckor megtartott együttes üléséről. Elérhető: www.parlament.hu/documents/static/biz41/bizjkv41/NBB/1805142.pdf (A letöltés dátuma: 2019. 11. 09.)

$51 \quad$ A korábbi BM Rendészeti Államtitkárság vezetőjének számos funkcióját átvevő Közbiztonsági Főigazgató polgári nemzetbiztonsági tevékenység irányításával kapcsolatos feladatait a 11/2018. (VI. 12.), majd a 23/2018. (XII. 21.) BM utasítása szabályozta. 
A fenti intézkedésekkel párhuzamosan - a 94/2018. (V. 22.) Korm. rendelet kiadásával - az Információs Hivatal kormányzati irányítása (annak elsősorban közigazgatási szegmense) visszakerült a külügyi tárca vezetőjéhez. A Külgazdasági és Külügyminisztérium szervezetén belül ennek a feladatnak a támogatására jött létre a Polgári Hírszerzésért felelős Államtitkárság. ${ }^{52}$ Ugyanakkor 2018 tavaszán döntés született arról is, hogy a kormány nemcsak megőrzi, de az IH és a KNBSZ által megszerzett értesülések integrált hasznosításával - a korábbiaknál komplexebbé teszi a hírszerzési információk kormányzati döntéshozatal centrumába történő közvetlen becsatornázásának, illetve az ezt megalapozó hírigények koordinált meghatározásának 2012-ben kialakított modelljét. A fenti célkitűzés szervezeti hátterét a 94/2018. (V. 22.) Korm. rendelettel létrehozott Miniszterelnöki Kormányiroda szervezeti rendjébe illesztett Nemzeti Információs Államtitkárság (a továbbiakban: NIÁT) teremtette meg. A miniszterelnökkel, a kormány tagjaival, valamint a stratégiai fontosságú állami és gazdasági intézmények vezetőivel közvetlen kapcsolatban lévő nemzeti információs államtitkár részt vesz a Nemzetbiztonsági Kabinet, illetve Nemzetbiztonsági Munkacsoport ülésein, közremúködve e testületek döntés-előkészítő és koordinációs tevékenységében. A hírszerző szolgálatok vezényelt tagjaiból és kormánytisztviselőkből álló szervezet a miniszterelnök 3/2018. (VI. 11.) ME utasításában foglaltakkal összhangban:

- végzi a kormány tagjai által a hírszerzés számára megfogalmazott információs igények összesítését és az IH és a KNBSZ számára (szükség esetén módszertani javaslatokkal kiegészített formában) történő továbbítását;

- a kormányzati fókuszpontok ismeretében orientálja a hírszerző szolgálatok értékelő-elemző és tájékoztató tevékenységét;

- a nemzetbiztonsági szolgálatoktól beérkező információk koordinációjával segíti a miniszterelnök irányító hatáskörének hatékony érvényesülését;

- valamint a hírszerzési tevékenységet érintő kérdésekben javaslatot, illetve előterjesztést tehet, szükség estén kezdeményezve a kormány illetékes tagjának intézkedését. ${ }^{53}$

A 17/2018. (VI. 11.) KKM utasítás alapján az államtitkárság elsősorban a polgári hírszerzést érintő közigazgatási - ezen belül jogszabályelőkészítési, költségvetési és ellenőrzési - feladatok végrehajtásában támogatja az irányító minisztert.

53 A NIÁT létrehozásával kapcsolatos kormányzati célkitúzéseket és a szervezet feladatrendszerét, valamint múködésének alapelveit ismerteti: HóDos 2018, 5-17. 


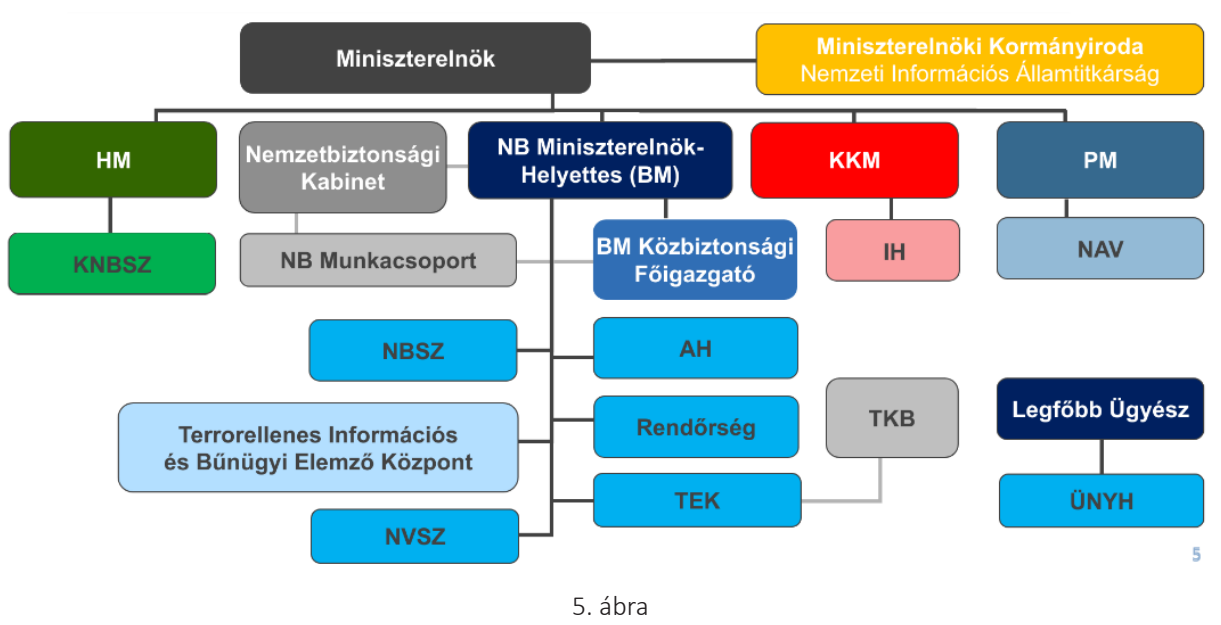

A titkos információgyüjtést folytató szervek kormányzati irányitása 2018 nyarától

Forrás: a szerző szerkesztése

A negyedik Orbán-kormány megalakulását követő kormányzati intézkedésekkel megvalósult a magyar nemzetbiztonsági (és rendvédelmi) struktúra egészét lefedő koordinációs folyamatok szervezeti hátterének kialakítása. A TIBEK által a rendvédelem és a polgári nemzetbiztonsági szféra belföldi komponenseit 2016-tól összefogó információfúziós rendszer 2018 nyarán kiegészült a nemzeti hírszerző képességek korábbiaknál összehangoltabb hasznosítását lehetővé tevő, de az IH és a KNBSZ szektoriális információs csatornáit megőrző (intézményesített) mechanizmussal. Ez utóbbi megoldás létrejöttét - a Magyarországot érintő 21. századi komplex biztonsági kihívások konstans elemei mellett - jelentős mértékben elősegítette a korábbiaknál aktívabb, a konfliktusokat akár európai intézmények szintjén is felvállaló külpolitikai doktrínához kapcsolódó hírigények bővülése, illetve a hírszerzés tevékenységét érintő kormányzati elvárások ezzel párhuzamos növekedése. ${ }^{54}$

Az institucionalista megközelítéssel írt elemzések sajátja, hogy az elvégzett vizsgálat perspektivikus kitekintés nélkül jellemzően csak pillanatfelvételt tud nyújtani az intézményfejlődés aktuális állapotáról, szerencsés esetben kiegészítve ezt a rendszerben azonosítható nyitott kérdések értékelésével. A szerző - egyetértve azzal a megközelítéssel, amely szerint a nemzetbiztonsági igazgatás konkrét rendszerének kialakítása a mindenkori kormányzat (politikai) döntésének függvénye - nem kíván találgatásokba bocsátkozni az elmúlt három évtizedben létrejött koordinációs szervezetek és mechanizmusok lehetséges továbbfejlődési irányaival kapcsolatban. A tanulmány zárásaként azonban érdemes felhívni arra a figyelmet, hogy nemzetbiztonsági

$54 \quad$ A kormányzat kül-és biztonságpolitikai célrendszerének súlyponti elemeinek összegzését végezte el a polgári hírszerzés irányításának átvételére készülő külgazdasági és külügyminiszter a kinevezése előtti parlamenti bizottsági meghallgatásán. Jegyzőkönyv az Országgyűlés Nemzetbiztonsági bizottságának 2018. május 15-én megtartott üléséről. 5-10. Elérhető: www.parlament.hu/documents/static/biz41/bizjkv41/NBB/1805151.pdf (A letöltés dátuma: 2019. 11. 06.) 
tevékenység lehetséges korszerűsítését érintő szakmai tudományos munkák a „jövőbe tekintés" részeként visszatérően foglalkoznak a szolgálatok feladatait is érintő stratégiaalkotási folyamatok szerepével. ${ }^{55}$ A 2012-ben megalkotott (hatályos) Nemzeti Biztonsági Stratégia (NBS) 48. pontja a korábban kiadott változatokhoz képest részletesebben jelenítette meg a „hírszerző és elhárító” tevékenységgel szembeni kormányzati elvárásokat, köztük „a hazai szervek koordinált tevékenységre” vonatkozó igényt. ${ }^{56}$

2016 őszén vált ismertté a kormányzat azon szándéka, hogy a Magyarországot érintő aktuális kihívások - különösen a tömeges migráció, az ismét intenzívebbé váló európai terrorfenyegetés jelentette kockázatok - ismeretében aktualizálni kívánja az NBS szövegét. ${ }^{57} 2019$ nyarán a honvédelmi tárca vezetője már a szakértői szintű egyeztetésekről tájékoztatta az Országgyúlés Nemzetbiztonsági bizottságát, jelezve, hogy annak lezárulása után a kormány elé kerül az NBS új változata. ${ }^{58}$ Fontos tisztázni, hogy a klasszikus stratégiaalkotási folyamatok elsősorban a védendő/érvényesítendő érdekek azonosítására és az aktuális helyzetelemzésre épülő cél- és feladatrendszer meghatározására fókuszálnak, kerülve a konkrét intézményrendszer egyes elemeinek megjelenítését. Jelen tanulmány által vizsgált témakör szempontjából ettől függetlenül érdemes lesz megvizsgálni, hogy az elmúlt időszakban kialakított koordinációs mechanizmusok hatékony múködtetésével kapcsolatos kormányzati elvárások, valamint az ennek kibontására bővebb lehetőséget nyújtó nemzetbiztonsági „ágazati” stratégia megalkotására vonatkozó felhívás megjelenik-e az aktualizált NBS szövegében.

\section{Felhasznált irodalom}

BARÁTH Magdolna (2010): Az állambiztonságtól a nemzetbiztonságig. In OKVÁTH Imre szerk.: Állambiztonsági és rendszerváltás. Budapest, L’Harmattan Kiadó.

BÁLINT László (2017): Terrorelhárítási Információs és Bűnügyi Elemző Központ. In RESPERGER István szerk.: A nemzetbiztonság elmélete a közszolgálatban. Budapest, Dialóg Campus Kiadó.

BÁLINT László (2012): Szervezeti lehetőségek a bűnügyi és nemzetbiztonsági kockázatok kezelésében. In: GAÁL Gyula - HAUTZINGER Zoltán szerk.: Pécsi Határőr Tudományos Közlemények XIII. Pécs. DOI: https://doi.org/10.33895/mtk-2019.11.04

55 Ebben a témakörben többek között megemlíthetők Izsa Jenő (2007), Solti István (2017), Drusza Tamás (2017) és Dávid Ferenc (2017a/b) elemzései.

56 A 1035/2012. (II. 21.) Korm. határozattal kiadott NBS megalkotására a Magyar Köztársaság biztonság-és védelempolitikájának alapelveiről szóló 94/1998. (XII. 29.) OGY határozata adott mandátumot a kormánynak. Az NBS - korábbi változataihoz: a 2144/2002. (V. 6.) Korm. határozat, majd a 2073/2004. (IV. 15.) Korm. határozat által kiadott dokumentumokhoz hasonlóan - tartalmazza a kormány által jóváhagyott, aktuális helyzetelemzésre épülő biztonságpolitikai célkitűzéseket, amelyeket a nemzetbiztonsági szolgálatok „lebonthatnak" saját (múveleti) tevékenységük szintjére.

572016 szeptemberében a honvédelmi miniszter arról adott tájékoztatást az Országgyűlés honvédelmi és rendészeti bizottsága előtt, hogy új nemzeti biztonsági stratégia kidolgozásáról kezdődtek egyeztetések a Belügyminisztériummal és a Külgazdasági és Külügyminisztériummal. Elérhető: https://honvedelem.hu/cikk/ munkacsoport-alakul-a-nemzeti-biztonsagi-strategia-felulvizsgalatara/ (A letöltés dátuma: 2019. 11. 07.)

58 Elérhető: https://magyarnemzet.hu/belfold/benko-tibor-magyarorszag-biztonsagi-helyzete-stabil-7034339/ (A letöltés dátuma: 2019. 11. 07.) 
URBÁN ATTILA: A koordinációs folyamatok intézményi hátterének evolúciója...

BÉRES János szerk. (2018): Külföldi nemzetbiztonsági szolgálatok. Budapest, Zrínyi Kiadó.

DÁVID Ferenc (2017a): Nemzeti biztonság és nemzetbiztonság a stratégiaalkotásban. Nemzetbiztonsági Szemle, 5. évf. 3. sz. 5-22.

DÁvID Ferenc (2017b): Nemzetbiztonság és szervezetrendszer. NKE, Államtudományi Mühelytanulmányok, 14. sz.

DEZső Lajos - HAJAS Gábor (1998): A nemzetbiztonsági tevékenységre vonatkozó jogszabályok. Budapest, HVG-ORAC Lap- és Könyvkiadó.

DRUSzA Tamás (2017): A nemzetbiztonsági stratégiáról a Nemzeti Katonai Stratégia tükrében. Nemzetbiztonsági Szemle, 5. évf. 3. sz. 77-87.

HARASZTI György szerk. (2007): Vallomások a holtak házából. Budapest, Corvina Kiadó. Hetesy Zsolt (2011): A titkos felderités. PhD-értekezés. Pécs, Pécsi Tudományegyetem Állam- és Jogtudományi Kar Doktori Iskola. Elérhető: http://ajk.pte.hu/sites/ajk. pte.hu/files/file/doktori-iskola/hetesy-zsolt/hetesy-zsolt-vedes-ertekezes.pdf (A letöltés dátuma: 2019. 11. 02.)

Hetesy Zsolt (2013): Másodlagos nemzetbiztonsági kihívások. Hadtudomány, 23. évf. 1-2. sz. 23-29.

HÉJJA István (2014): Nemzetbiztonsági szervezeti modellek. In DoBÁK Imre szerk.: A nemzetbiztonság általános elmélete. Budapest, NKE NBI.

Hódos László (2018): Gondolatok a nemzeti hírszerző képesség koordinációjáért felelős szerv közjogi helyzetéről. Szakmai Szemle, 16. évf. 4. sz. 5-16.

IZSA Jenő (2007): Javaslatok a nemzetbiztonsági/titkosszolgálati stratégia kidolgozásához. Hadtudomány, 17. évf. 1. sz. Elérhető: http://mhtt.eu/hadtudomany/2007/1/2007_1_4.html (A letöltés dátuma: 2019. 11. 02.)

IZSA Jenő (2009): Nemzetbiztonsági reform - átmenetileg elhalasztva. Nemzet és Biztonság, 2. évf. 1. sz. 49-57.

Jensen, Carl J. et al. (2017): Bevezetés a hírszerzésbe. Budapest, Antall József Tudásközpont.

KÁRPÁTI György (2006): A nemzetbiztonsági szolgálatok szervezeteinek racionalizálása. Hadtudomány, 16. évf. 4. sz. 99-101.

KovÁcs Zoltán András - DoBÁk Imre (2017): Korszakváltások a magyar nemzetbiztonsági intézményrendszerben (1990-2016). In FINSZTER Géza - SABJANICS István szerk.: Biztonsági kihívások a 21. században. Budapest, Dialóg Campus Kiadó.

Kovács Zoltán András (2019): A polgári elhárítás negyedszázada (1989-1996). In DRUSzA Tamás szerk.: A magyar elhárítás fejlődése. Budapest, Dialóg Campus Kiadó.

KURTÁN Sándor (2008): Tanulmányozzuk-e James Bondot? Politikatudomány és titkosszolgálat. Politikatudományi Szemle, 17. évf. 2. sz. 125-142.

KURTÁN Sándor (2009): Titkosszolgálatok Magyarországon 1988-2008. In SÁNDOR Péter - StuMPf Anna - VASS László szerk.: Magyarország Politikai Évhuszadkönyve. Budapest, DKMKA.

KRAHULCSÁn Zsolt (2013): A párt belügye. A politikai rendőrség és az MSZMP a korai Kádár-korszakban, 1956-1962. Budapest, ÁBTL-L'Harmattan.

LowentHAL, Mark M. (2017): Hírszerzés. A titkoktól a politikai döntéseikig. Budapest, Antall József Tudásközpont.

MüLLER Rolf (1999): Napi operatív információs jelentések, 1979-1989. In GYARMATI György szerk.: Trezor 1., a Történeti Hivatal évkönyve. Budapest, Történeti Hivatal. 
OMAND, David (2011): Securing the State. London, Hurst \& Company.

RÉVÉSz Béla (2000): Az Ellenzéki Kerekasztal és az állambiztonság. In Bozókı András szerk.: A rendszerváltás forgatókönyve. Budapest, Új Mandátum.

Rolington, Alfred (2015): Hírszerzés a 21. században. A mozaikmódszer. Budapest, Antall József Tudásközpont.

SolTI István (2014): A nemzetbiztonsági stratégia a Nemzeti Biztonsági Stratégia tükrében. Nemzetbiztonsági Szemle, 7. évf. 3. sz. 47-60.

SABJANICS István (2007): Gondolatok a polgári titkosszolgálatok közjogi helyzetéről. In PÁlL István szerk.: Közjogi Államtudományi Kutatócsoport Publikációi. III. kötet. Budapest, Szent István Társulat.

VARGA Krisztián (2015): Ellenség a baloldalon. Politikai rendörség a Horthy-korszakban. Budapest, Jaffa.

TÜтTő Szabolcs (2007): A nemzetbiztonsági szolgálatok feladatrendszere az új kihívások tükrében. Hadtudomány,17. évf. 3. sz. 24-36.

URBáN Attila (2003): Magyar állambiztonsági szolgálatok (1962-1980). Múltunk, 48. évf. 3. sz. 3-74.

\section{Internetes források}

www.abparancsok.hu/sites/default/files/parancsok/10_1837_1967.pdf (A letöltés dátuma: 2019. 11. 01.)

Jelentés az Állami Számvevőszék 2007. évi tevékenységéről. (2018. április). Elérhető: https://asz.hu/storage/files/files/tajekoztato_az_allami_szamvevoszek_eves_tevekenysegerol/0803j000. pdf?ctid=271 (A letöltés dátuma: 2019. 10. 25.)

https://honvedelem.hu/cikk/munkacsoport-alakul-a-nemzeti-biztonsagi-strategiafelulvizsgalatara/ (A letöltés dátuma: 2019. 11. 07.)

https://magyarnemzet.hu/belfold/benko-tibor-magyarorszag-biztonsagi-helyzetestabil-7034339/ (A letöltés dátuma: 2019. 11. 07.)

\section{Jogforrások}

1995. évi CXXV. törvény a nemzetbiztonsági szolgálatokról

2000. CXXVI. törvény (Parlamenti jegyzőkönyvek, 2000. szeptember 27.)

26/1990. (II. 14.) MT rendelet a nemzetbiztonsági feladatok ellátásának átmeneti szabályozásáról

3039/1990. sz. MT határozat (1990. február 02.) a nemzetbiztonsági szolgálatok létrehozásáról és működési feltételeiről

1/2018. (V. 22.) ME rendelet

47/1996. (VI. 7.) OGY határozat

1243/2018. (V. 22.) Korm. határozat 2010/2007. (I. 30.) Korm. határozat 232/2010. (VIII. 19.) Korm. rendelet 295/2010. (XII. 22.) Korm. rendelet 
1308/2011. (IX. 6.) Korm. határozat 1035/2012. (II. 21.) Korm. határozat 152/2014. (VI. 6.) Korm. rendelet 15/2014. (IX. 5.) BM utasítás 1988/2015. (XII. 28.) Korm. határozat 17/2018. (VI. 11.) KKM utasítás

Jegyzőkönyv az NBB 2012. július 3-i üléséről. Elérhető: www.parlament.hu/internet/ plsql/ogy_biz.keret_frissit?p_szerv=\&p_fomenu=20\&p_almenu=20\&p_ckl=39\&p_ biz=A349\&p_rec=\&p_egys=\&p_nyelv=HU (A letöltés dátuma: 2019. 11. 09.)

Jegyzőkönyv az NBB 2012. szeptember 11-i üléséről. Elérhető: www.parlament. hu/internet/plsql/ogy_biz.keret_frissit?p_szerv=\&p_fomenu=20\&p_alme$n u=20 \& p \_c k \mid=39 \& p \_b i z=A 349 \& p \_r e c=\& p \_e g y s=\& p \_n y e l v=H U$ (A letöltés dátuma: 2019. 11. 09.)

Jegyzőkönyv az Országgyűlés Honvédelmi és rendészeti bizottságának, valamint Nemzetbiztonsági bizottságának az Országgyúlés Irodaháza III. tárgyalójában 2018. május 14-én, hétfőn 13 óra 30 perckor megtartott együttes üléséről. Elérhető: www.parlament.hu/documents/static/biz41/bizjkv41/NBB/1805142.pdf (A letöltés dátuma: 2019. 11. 09.)

Jegyzőkönyv az Országgyűlés Nemzetbiztonsági bizottságának 2018. május 15-én megtartott üléséről. 5-10. Elérhető: www.parlament.hu/documents/static/biz41/ bizjkv41/NBB/1805151.pdf (A letöltés dátuma: 2019. 11. 06.)

Kövér László házelnök módosító javaslata az egyes rendvédelmi tárgyú törvények módosításáról, valamint az azzal összefüggő további törvényjavaslatokról. (2011. november 30.) Elérhető: www.parlament.hu/irom39/05004/05004-0022. pdf (A letöltés dátuma: 2019. 11. 13.)

Országgyúlési Napló, 2014-2018. országgyűlési ciklus. Budapest, 2016. április 27., szerda 146. sz. 